Article

\title{
Circular Strategies Enabled by the Internet of Things-A Framework and Analysis of Current Practice
}

\author{
Emilia Ingemarsdotter *(D), Ella Jamsin, Gerd Kortuem and Ruud Balkenende \\ Faculty of Industrial Design Engineering, Delft University of Technology, 2628 CE Delft, The Netherlands; \\ e.jamsin@tudelft.nl (E.J.); g.w.kortuem@tudelft.nl (G.K.); a.r.balkenende@tudelft.nl (R.B.) \\ * Correspondence: e.k.ingemarsdotter@tudelft.nl
}

Received: 25 September 2019; Accepted: 10 October 2019; Published: 15 October 2019

check for updates

\begin{abstract}
This paper focuses on how the Internet of Things (IoT) could contribute to the transition to a circular economy (CE), through supporting circular business model and design strategies. While literature has highlighted the opportunities for IoT to support circular strategies in business, little has been published about actual implementations in practice. The aim of this study was therefore to understand how companies to date have implemented IoT for circular strategies, and how these implementations compare to the range of opportunities described in literature. To that end, a two-step approach was followed. Firstly, building on academic literature, a framework was developed which categorizes different IoT-enabled circular strategies. The framework recognizes tracking, monitoring, control, optimization, and design evolution as IoT capabilities. Efficiency in use, increased utilization, and product lifetime extension are distinguished as circular in-use strategies, while reuse, remanufacturing, and recycling are distinguished as circular looping strategies. The framework complements previously published work, as it adds additional detail to the categorization, and allows for easy mapping of diverse cases. Secondly, 40 cases from practice were analyzed and mapped to the framework. This way, practice-based insights were derived about the current distribution of IoT-enabled circular strategies implemented in practice. The results show that current implementation of IoT-enabled circular strategies mainly supports two strategies in the use phase: efficiency in use and product lifetime extension. Only a small number of the reviewed cases display IoT-enabled looping (reuse, remanufacturing, and recycling). Similarly, few cases describe 'design evolution' for CE, i.e., the feedback of data from products in use to support circular design. Based on these results, this study identifies the need for future research to further investigate why IoT-enabled looping strategies and design evolution for circular strategies have not been implemented to scale.
\end{abstract}

Keywords: circular economy; digitalization; sustainable business models; product service systems

\section{Introduction}

The circular economy (CE) conceptualizes an envisioned global economy which is "restorative and regenerative by design" [1] and which simultaneously considers environmental impact, resource scarcity, and economic benefits [2]. In practice, CE-related issues-such as the reduction of waste, emissions, and supply risk-are spurring innovations in business models, product designs, materials, and supply chain configurations. Circular business approaches focus on "maintaining the highest level of economic value of products, components and materials for as long as possible, while at the same time ensuring that the environmental impact over time is as low as possible" [3]. In a CE, businesses need to find ways to make profit from "the flow of materials and products over time" 
in a system where products and materials are continually reused [4]. In particular, service-oriented business models, such as product service systems (PSS), are often mentioned for their potential to reduce environmental impacts [5], and support the CE [6]. PSS have been defined as innovation strategies that "shift the business focus from designing and selling physical products only, to designing and selling a system of products and services which are jointly capable of fulfilling specific client demands" [7]. On the product level, circular design strategies prescribe a lifecycle perspective, targeting product features such as durability, upgradability, reparability, and recyclability [3].

The Internet of Things (IoT) has been described as a new paradigm in which everyday objects can sense and communicate [8] leading to completely new possibilities for information exchange [9] and recent reports have emphasized the theoretical potential for IoT to support the transition to a CE [10-12]. The IoT has been defined as a "system of uniquely identifiable and connected constituents capable of virtual representation and virtual accessibility leading to an Internet-like structure for remote locating, sensing, and/or operating the constituents with real-time data/information flows between them, thus resulting in the system as a whole being able to be augmented to achieve a greater variety of outcomes in a dynamic and agile manner" [13] (p. 6). The IoT brings about the possibility to collect large amounts of data from products in use. The business opportunities of the IoT are thus linked to developments in other technologies such as real-time computing, machine learning, and big data analytics [14]. The implementation of IoT in a company can support real-time data processing and optimized resource use which could lead to the development of more competitive products and more profitable business models [15]. As the IoT takes form and expands, with a growing number of smart and connected products [16], physical objects are increasingly able to understand and react to their environment [17]. This allows for improved visibility of assets in the field, with implications for CE. For example, manufacturers can gain knowledge about the current and predicted condition of products, and thereby build services based on actual performance and use [18]. Moreover, connecting products to the IoT can support monitoring of products and parts throughout their lifecycles, and provide decision support for companies implementing circular business models [2].

Previous research has categorized the opportunities of IoT for CE into 'smart' maintenance, reuse, remanufacturing, and recycling [19]. However, publications covering empirical work, and in particular case study research, are still limited [20]. Specifically, extant literature does not give an answer to how current practice compares to the envisioned opportunities of IoT for CE.

In this paper, we therefore aim to better understand how IoT is currently implemented for CE in practice, and how that compares to the literature about how IoT might support the CE. To this end, we aim to answer the following research question: How have companies to date implemented IoT for circular strategies and how are these implementations distributed between the opportunities anticipated in literature? To answer this question, we also pose the following sub-question: How can IoT-enabled circular strategies be categorized in a framework which enables mapping a variety of company cases?

To answer these questions, we first provide a brief overview of current literature on IoT enabled CE (Section 2). Subsequently, we explore literature in the fields of IoT and CE to develop a framework that categorizes IoT-enabled circular strategies (Section 4). We then collect examples from practice of current IoT implementations for CE and map them to the framework (Section 5). The results are discussed in Section 6, and the methodology is presented in Section 3.

\section{Background}

Existing literature about IoT within the context of CE is sparse but growing [20]. While there is a large pool of literature available in the fields of IoT and CE independently, there is still limited research published in the nexus between the two [21], and there is a need for more research to systemically map CE approaches to emerging digital technologies [22]. Below, we summarize previous work that discusses how IoT could be used throughout the lifecycle of a product to reduce environmental impact, prolong product lifetimes, and close material loops. 
In a review paper on digital technologies in the circular economy, Pagoropoulos et al. [23] noted that IoT can enable monitoring of the health and actions of connected products. Salminen et al. [24] discussed that increasing intelligence and automation can create new business opportunities and help optimize existing operations that are favorable in a circular economy, while Spring and Araujo [25] argued that "smart products" allow for "connected, rich biographies of products" which can support activities such as maintenance and reverse logistics, especially when products "circulate beyond the direct governance of one coordinating firm". Jensen and Remmen [26] similarly found that digitalization could potentially support product lifecycle management and the integration of information about, for example, material composition of products, which could stimulate high-quality recycling and reuse. Roy et al. [27] emphasized the role of "life cycle "big data' analytics" for continuous maintenance of products". Lopes de Sousa Jabbour et al. [28] discussed the relationship between Circular Economy, Industry 4.0, and sustainable operations management. They suggested, for example, that 'product passports' can improve recovery, and that tracking of products can enable reverse logistics. Gligoric et al. [29] highlighted the lack of a unified ontology for data exchange to support circular strategies, and presented a technology for printing sensors which could serve as product passports. These passports would carry data about, for example, material composition, recyclability, and potential for reuse.

Only a small number of peer-reviewed case studies have been published that describe the use of IoT for improved circularity of products and services in practice. Baines et al. [30] interviewed representatives from four companies about how ICT can support the implementation of advanced services. They provide examples of how data from connected trucks can support optimal fuel efficiency, and how data about the location and condition of trains can enable effective and efficient maintenance services. In the context of building equipment, Fargnoli et al. [31] highlighted how building information management systems can support more effective management of maintenance activities and enhance information exchange between stakeholders in the equipment lifecycle. Grubic and Jennions [32] performed a multiple case study in which they extracted factors that "characterise the application of remote monitoring technologies in the context of servitised strategies". They found that remote monitoring technology supports "a broad spectrum of product and service combinations, from warranty to availability contracts", and that a complex relationship exists between the technology and the servitized strategies. Ardolino et al. $[33,34]$ built on a literature review and a multiple case study to identify key digital capabilities for service transformation. In the context of performance-based contracts they found that the digital capabilities of 'usage monitoring' and 'prediction' could support the delivery of equipment uptime, and that the capability of 'adaptive control' could support services that promise specific levels of efficiency in product use. Lindström et al. [35] conducted a case study about recycling management optimization supported by IoT technology. They studied how a company transformed to a PSS provider, how they used IoT, and how the new set-up affected their customers. Kiritsis [36] studied the implementation of IoT for "closed-loop product lifecycle management" in 10 demonstrator projects, for example describing how IoT was used to identify and assess the condition of vehicle components available for reuse. Moreno et al. [37] described a case in which a 3D-printed shoe with integrated sensors could alert the user when repair was needed.

Two frameworks have previously been published that give an overview of the enabling effects of digitalization on circular strategies in business [19,34]. Alacayaga et al. [19] reviewed literature in the intersections between IoT, PSS and CE and proposed a concept of 'smart-circular PSS' including 'smart' use, maintenance, reuse, remanufacturing, and recycling. The authors give some indication about how different strategies are currently implemented in practice, stating that 'smart use' and 'smart maintenance' have high usage, while 'smart reuse' has medium usage, 'smart remanufacturing' low usage, and 'smart recycling' very low usage. However, this assessment is not clearly based on a review of cases from practice.

Bressanelli et al. [38] conducted a literature review and a single case study to identify 'usage-focused business model functionalities' that could be supported by IoT and big data analytics, and which had impact on circular strategies. The eight functionalities extracted were the following: improving 
product design, attracting target customers, monitoring and tracking products activity, providing technical support, providing preventive and predictive maintenance, optimizing the product usage, upgrading the product, and enhancing renovation and end-of-life activities.

The framework in [38] was designed to analyze a single company case according to IoT-enabled circular strategies applied, while the framework in [19] was designed as a way to structure findings from literature. The frameworks do not explicitly distinguish between types of IoT solutions, which limits the potential for using the frameworks to identify additional opportunities in that dimension. Moreover, the frameworks were not designed to facilitate mapping and comparison between different cases.

To fulfill the aim of this paper, to better understand how IoT is currently implemented for CE in practice, and how that compares to the literature about how IoT might support the CE, we develop a framework which complements previous work by presenting a structured way of categorizing IoT-enabled circular strategies, and which facilitates mapping of diverse cases according to the IoT capabilities used, as well as the circular strategies enabled. We subsequently use this framework to map a larger set of cases from practice, in order to provide insights into how current implementation in practice is distributed between the different IoT-enabled circular strategies.

\section{Method}

To achieve the aim of this paper, we first developed a framework to categorize IoT-enabled circular strategies, and then used the framework to map a set of cases from practice. The research was carried out in four main steps: (1) rapid literature review and framework development; (2) identification of cases; (3) selection of relevant cases; and (4) analysis and mapping of cases to the framework (see Figure 1).

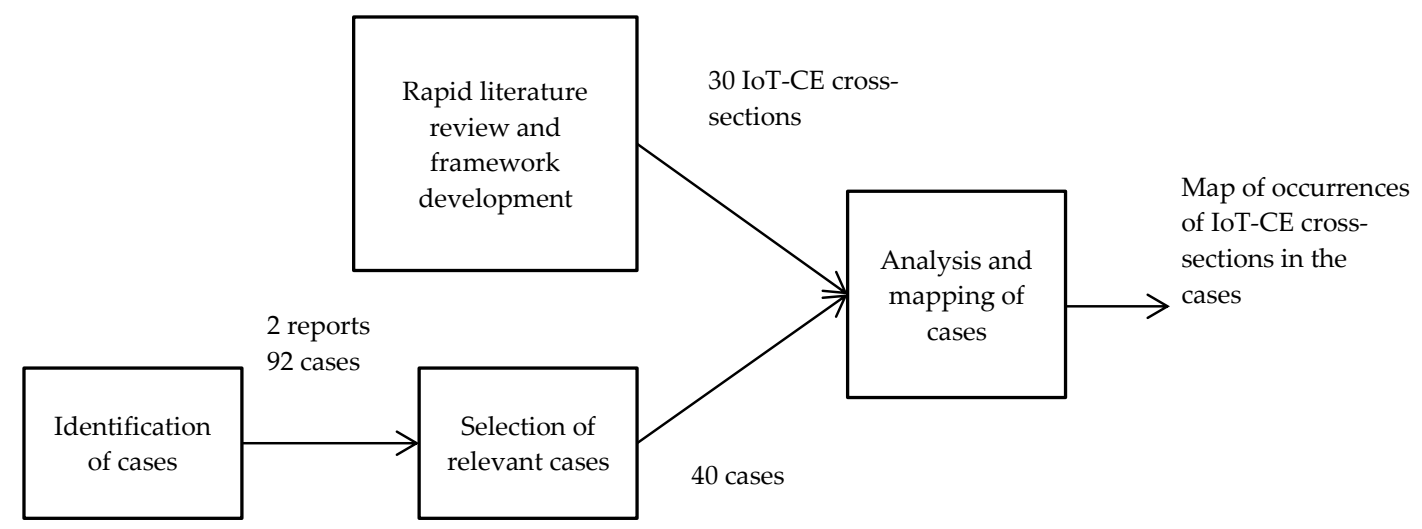

Figure 1. Steps in method to develop the framework, identify and select the cases, and map the cases to the framework.

\subsection{Rapid Literature Review and Framework Development}

In order to categorize the company cases, a framework was developed which distinguishes between different categories of IoT capabilities on the one hand, and different categories of circular strategies on the other hand. To identify the key capabilities underpinning IoT and the key strategies applied in CE, a rapid literature review was conducted [39]. This methodology was considered appropriate given the focused search target, the small number of academic sources specific to IoT-enabled CE, and the broad scope of the fields of IoT and CE as such. The goal of the review was to identify an established view among scholars about IoT capabilities and circular strategies, respectively. To this end, review papers were prioritized. Moreover, papers with few citations were excluded based on their low or, in the case of recent publications, still unclear scientific impact. In the field of IoT, papers were collected from academic journals based on the following criteria: the papers should (1) provide an overview of the technology and its enabling capabilities; (2) be general in the sense that the results could be 
applied across industries; and (3) be well cited ( $>15$ citations) to demonstrate that the findings are recognized by other researchers. The search was performed using the scientific databases Scopus and Web of Science, and the selection resulted in eight articles published in academic outlets between 2010 and 2016.

In the field of $\mathrm{CE}$, academic literature was consulted to identify existing frameworks describing product and business model design strategies. Similar selection criteria were applied. The papers should (1) explicitly focus on deriving design strategies for CE, and (2) present results which could be applied generally (not case or industry specific), and (3) have more than 15 citations. The search was performed using the scientific databases Scopus and Web of Science, and the selection resulted in five articles published in academic outlets between 2014 and 2017.

The IoT capabilities and circular strategies described in literature were interpreted and grouped together into categories, using frameworks from ' grey' literature as starting points. In the IoT dimension, we started from the four categories-monitoring, control, optimization and autonomy-as presented in the framework of capabilities of smart connected products in [16]. We then used the academic literature sources to extract additional IoT capabilities.

Similarly, to define categories of circular strategies, we built on the often cited framework presented by the Ellen MacArthur Foundation [1], which identifies five main circular strategies: share, maintain/prolong, reuse/redistribute, refurbish/remanufacture, and recycle. Based on academic literature that presents design strategies for $\mathrm{CE}$, we identified additional strategies to be added to the framework.

Finally, we excluded categories in both dimensions that did not prove to be relevant for the purpose of the framework. The framework development process is explained in more detail in Section 4.

\subsection{Identification of Cases from Practice}

Since there are few case studies published in academic literature about how IoT can be used for $\mathrm{CE}$, 'grey' literature was used to extract cases from practice. Reports were scanned based on the following criteria: (1) it should discuss the application of IoT technology, while also taking into account environmental aspects; (2) it should review a large set of cases $(>20)$, to allow for comparable case descriptions; and (3) it should not be directly authored by the ICT industry, to avoid bias. Based on these criteria, two reports were identified as suitable sources for a comprehensive overview of relevant company cases. One of the reports originates from the field of CE and is compiled by the Ellen MacArthur Foundation [10], while the other report comes from the field of IoT and is compiled by the Harvard Business Review [16]. Both organizations are well known knowledge sources in their respective fields, and were judged to be reliable sources for the case review. The two reports present a combined total of 92 cases, describing a wide range of IoT and CE implementations in business. Considering the high number of cases reviewed in the two reports and the broad scope taken by both organizations in assembling the collections of cases, we treated the combined set of cases, although certainly not complete, as a representative sample of current practice of using IoT for CE in business.

\subsection{Selection of Relevant Cases}

From the 92 cases presented in in the two reports [10,16], we selected 40 cases to analyze in this study. The selection process of going from 92 cases to 40 cases is depicted in Figure 2. The following selection criteria were applied: (1) the case should be described in enough detail to allow for further analysis; (2) the case should depict the use of a circular strategy; (3) the case should be centered around the use of a IoT-enabled product; and (4) the case should describe an actual implementation to date. 22 cases were excluded because we lacked information to do the subsequent analysis and mapping. For example, if a large manufacturer was mentioned without any description regarding the product or service considered, the case could not be further analyzed. The remaining 70 cases were briefly analyzed in terms of relevance to IoT and CE. 12 cases were excluded because they did not describe 
any impact in terms of $\mathrm{CE}$ or environmental sustainability. Examples of cases that were excluded based on this criterion are FitBit (captures data about daily activities to support a healthy lifestyle) and iRobot Roomba (autonomous vacuum cleaner that uses sensors to navigate). Nine cases were excluded because they did not show a strong enough IoT component, i.e., they did not include any interactions with a physical smart product. Examples here are AirBnB (online platform to match supply and demand for short stay rental apartments) and PayByPhone (app that makes it easier to pay for parking). Finally, since the focus of the paper was to understand current implementation, we excluded prototypes and start-ups. Nine cases were excluded based on this criterion, for example Aganza (platform for offering products in a 'pay-as-you-go' model) and Burba (smart bin prototype).

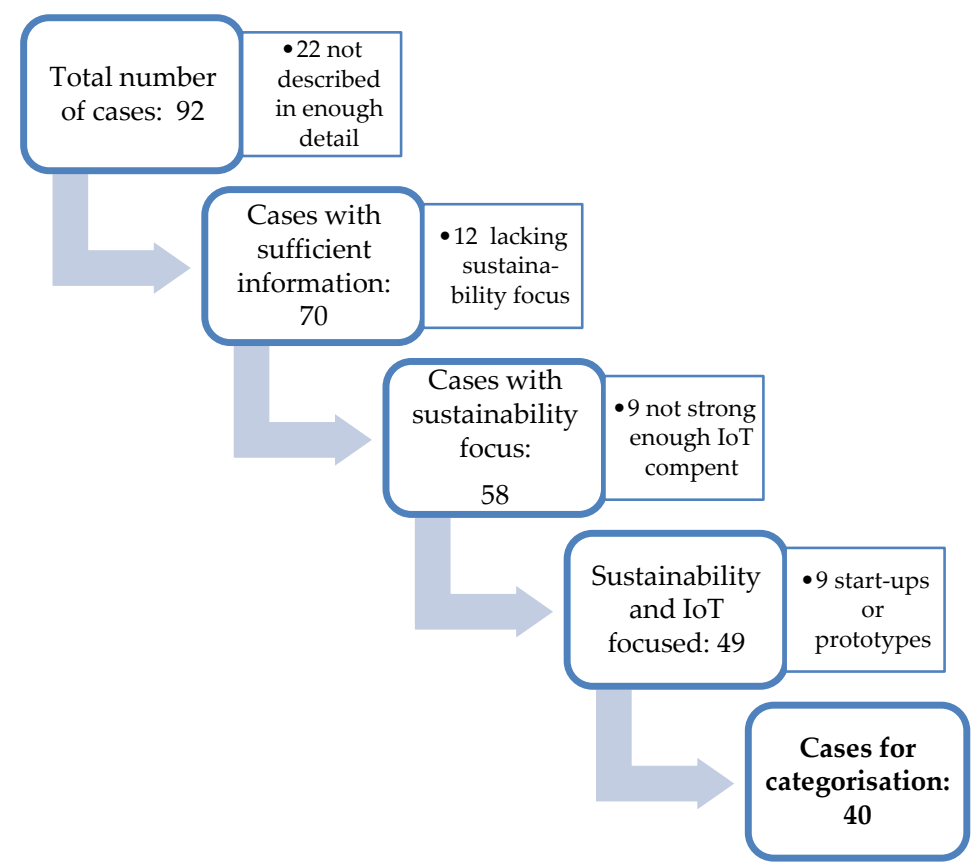

Figure 2. Process of selecting 40 cases for analysis.

\subsection{Analysis and Mapping of Cases}

For each of the selected cases, we read the description of the case in the publication where it was presented and highlighted information about the use of IoT, and about the implementation of circular strategies. When needed, additional data was retrieved from other sources, such as the company's website. Based on the data retrieved, we could map the case to the framework according to the definitions of IoT capabilities and circular strategies presented in Section 4. It should be noted that each case can display the use of several IoT capabilities and circular strategies. The mapping of all the cases, together with brief case descriptions, is provided in Appendix A.

\section{Framework}

This section describes how the framework was developed based on literature. We explain, separately, how we derive five categories in the IoT dimension and six categories in the CE dimension.

\subsection{IoT Capabilities}

\subsubsection{Categories in Literature}

While the exact terminology to describe IoT-related business opportunities varies between authors, we here synthesize core capabilities of the technology as found in literature.

Porter and Heppelmann [16] categorize the capabilities of 'smart, connected products' into four levels: monitoring, control, optimization, and autonomy. Monitoring relates to the ability of a product to 
provide information about its own use, and to sense its environment $[9,17]$. For example, monitoring can be applied for diagnostics and prognostics of products-in-use, in order to enhance maintenance services in PSS [40]. On the level of the business model, monitoring can support business models that are based on product access and/or performance, as pricing can be based on actual product usage [41]. Control refers to the ability to change product and system parameters. When a product is connected to the IoT, this control can happen remotely [42]. Moreover, if the product is equipped with the capabilities of monitoring and processing, it can control itself based on insights from monitoring conditional parameters [8]. Optimization can be described as the application of algorithms and analytics to in-use or historical data, to optimize output parameters, utilization, or efficiency [16]. Autonomy brings about an additional layer of self-coordination to the functionality of smart products, giving enhanced ability to control system complexity, still using the capabilities of monitoring, control, and optimization [43].

Additional capabilities, which are not explicitly considered in the framework by Porter and Heppelmann [16], can be extracted from literature. Firstly, an early development in the direction towards an IoT was the increased use of RFID technology to track products and parts [17,43]. RFID tags have, among other applications such as bank cards and road toll tags, been of large importance for supply chain management [42]. Secondly, some authors explicitly highlight communication, networking [42], and processing [17] as important IoT capabilities. Thirdly, an important business opportunity brought about by the IoT is that products and systems can provide feedback from the use phase back to design [30]. This data feedback can give insights into actual product use and performance, and thereby inform design improvements [41]. For example, this strategy can be used to identify weaknesses in current designs [44], or to evaluate how users react in real life to design interventions [45]. The idea of taking advantage of product-in-use data for design improvements is well established in the design of websites and software (e.g., [46]). In the design of physical products, the phenomenon is emerging in academic literature using terms like closed-loop design evolution [44] and data-enabled design [45].

Table 1 shows IoT capabilities described in previous literature, and how we map them to seven main categories: tracking, monitoring, control, optimization, design evolution, autonomy, and processing/networking/communication.

\subsubsection{Categories Selected}

Based on the reviewed IoT capabilities, we select five categories as relevant for our framework: tracking, monitoring, control, optimisation and design evolution (Table 2). Compared to the seven IoT capabilities presented in Table 1, we do not include autonomy or processing/networking/communication. The category of processing/networking/communication is excluded because it describes basic technical requirements needed to enable the other capabilities. The category of autonomy is excluded because it describes a feature that can be present to some level within all the other categories. For example, decisions about control and optimization can be taken by either a human or a machine, and many solutions show a combination of the two. 
Table 1. IoT capabilities described in literature.

\begin{tabular}{|c|c|c|c|c|c|c|c|c|}
\hline \multirow[b]{2}{*}{ Source } & \multirow[b]{2}{*}{ IoT Capability Described } & \multicolumn{7}{|c|}{ Categories of IoT Capabilities } \\
\hline & & Tracking & Monitoring & Control & Optimization & $\begin{array}{l}\text { Design } \\
\text { Evolution }\end{array}$ & Autonomy & $\begin{array}{l}\text { Processing/ } \\
\text { Networking/ } \\
\text { Communication }\end{array}$ \\
\hline \multirow{4}{*}{$\begin{array}{c}\text { Porter and } \\
\text { Heppelman [16] }\end{array}$} & Monitoring & & $\mathrm{x}$ & & & & & \\
\hline & Control & & & $\mathrm{x}$ & & & & \\
\hline & Optimization & & & & $\mathrm{x}$ & & & \\
\hline & Autonomy & & & & & & $\mathrm{x}$ & \\
\hline \multirow{3}{*}{ Grubic [40] } & Diagnostic & & $\mathrm{x}$ & & & & & \\
\hline & Prognostic & & $\mathrm{x}$ & & & & & \\
\hline & Feedback to R\&D & & & & & $\mathrm{x}$ & & \\
\hline \multirow{3}{*}{ Lightfoot et al. [30] } & $\begin{array}{l}\text { Visibility of condition, operating } \\
\text { characteristics, time in use }\end{array}$ & & $\mathrm{x}$ & & & & & \\
\hline & Visibility of location & $\mathrm{x}$ & & & & & & \\
\hline & $\begin{array}{l}\text { Feedback from the use phase to product and } \\
\text { service design }\end{array}$ & & & & & $\mathrm{x}$ & & \\
\hline \multirow{3}{*}{ Kortuem et al. [17] } & Sensing & & $\mathrm{x}$ & & & & & \\
\hline & Processing & & & & & & & $\mathrm{x}$ \\
\hline & Networking & & & & & & & $\mathrm{x}$ \\
\hline \multirow{7}{*}{ Whitemore et al. [9] } & Identifying, Tracking and Tracing & $\mathrm{x}$ & & & & & & \\
\hline & Sensing, Monitoring & & $\mathrm{x}$ & & & & & \\
\hline & Networking & & & & & & & $\mathrm{x}$ \\
\hline & Processing & & & & | & & & $x$ \\
\hline & Control & & & $\mathrm{x}$ & 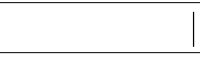 & & & \\
\hline & Data-supported decision making & & & & $\mathrm{x}$ & & & \\
\hline & Development of new business models & & & & & $\mathrm{x}$ & & \\
\hline
\end{tabular}


Table 1. Cont.

\begin{tabular}{|c|c|c|c|c|c|c|c|c|}
\hline \multirow[b]{2}{*}{ Source } & \multirow[b]{2}{*}{ IoT Capability Described } & \multicolumn{7}{|c|}{ Categories of IoT Capabilities } \\
\hline & & Tracking & Monitoring & Control & Optimization & $\begin{array}{l}\text { Design } \\
\text { Evolution }\end{array}$ & Autonomy & $\begin{array}{l}\text { Processing/ } \\
\text { Networking/ } \\
\text { Communication }\end{array}$ \\
\hline \multirow{5}{*}{ Gubbi et al. [42] } & Automatic identification & $\mathrm{x}$ & & & | & & & \\
\hline & Monitoring & & $\mathrm{x}$ & & | & & & \\
\hline & Actuation & & & $\mathrm{x}$ & 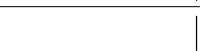 & & & \\
\hline & Automated decision making & & & & $\mathrm{x}$ & & $\mathrm{x}$ & \\
\hline & User interaction and communication & & & & | & & & $\mathrm{x}$ \\
\hline \multirow{3}{*}{ Atzori et al. [8] } & Identification & $\mathrm{x}$ & & & | & & & \\
\hline & Sensing & & $\mathrm{x}$ & & | & & & \\
\hline & Communication & & & & | & & & $\mathrm{x}$ \\
\hline \multirow{4}{*}{ Atzori et al. [43] } & $\begin{array}{l}\text { Readable, recognizable, locatable, } \\
\text { addressable }\end{array}$ & $\mathrm{x}$ & & & & & & \\
\hline & Controllable & & & $\mathrm{x}$ & | & & & \\
\hline & Embedded sensors and actuators & & $\mathrm{x}$ & $\mathrm{x}$ & | & & & \\
\hline & Self-governance and self-management & & & & | & & $\mathrm{x}$ & \\
\hline \multirow{2}{*}{ Xia et al. [44] } & Closed-loop design evolution & & & & | & $\mathrm{x}$ & & \\
\hline & Condition monitoring & & $\mathrm{x}$ & & 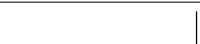 & & & \\
\hline
\end{tabular}


Table 2. IoT capabilities used in the framework.

\begin{tabular}{|c|c|}
\hline IoT Capability & Definition as Used in this Paper \\
\hline Tracking & $\begin{array}{l}\text { Information is available about a product's identity, } \\
\text { location, or unique composition. }\end{array}$ \\
\hline Monitoring & $\begin{array}{l}\text { Information is available about a product's use, } \\
\text { condition, or environment. This includes alerts and } \\
\text { notifications. }\end{array}$ \\
\hline Control & $\begin{array}{l}\text { Product functionality can be controlled through } \\
\text { software, based on predefined options. This includes } \\
\text { pushing regular updates. }\end{array}$ \\
\hline Optimization & $\begin{array}{l}\text { Goal-based improvements of operations are } \\
\text { supported by using advanced algorithms. }\end{array}$ \\
\hline Design Evolution & $\begin{array}{l}\text { The design of a product or service can be improved } \\
\text { based on data feedback from other lifecycle phases. } \\
\text { This includes functional upgrades as well as the } \\
\text { development of new products and services. }\end{array}$ \\
\hline
\end{tabular}

\subsection{Circular Strategies}

\subsubsection{Categories in Literature}

The CE is still a relatively new term in the academic literature, and a large number of different definitions have been published [47]. Previous research has shown that academics do not fully agree about which aspects should be included in the CE concept, and which not [48]. For the purpose of this paper, however, we choose to focus on design and business model strategies that can support environmental benefits in the CE. As we focus on IoT enabled products, we limit our search to strategies in the so-called technical metabolism [49], i.e., products that have the potential to be recovered and reused, partly or as an entity, through several life cycles. Within this scope, we find that previous literature can be condensed to a set of eight key circular strategies, as seen in Table 3, and as summarized below.

The Ellen MacArthur foundation [1] defines five main circular strategies: share, maintain/prolong, reuse/redistribute, refurbish/remanufacture, and recycle. Sharing of products has the potential to increase their utilization, which could reduce total number of products since one product could satisfy many peoples' need for a certain function [50]. Maintaining products and prolonging their lifetimes are mentioned as a circular strategy by, e.g., [4,51]. A core aspect of the CE is the looping of resources from a post-use stage back to production [3,4]. Remanufacturing and recycling have been researched extensively in the design for CE literature (e.g., [52,53]). Strategies for reuse of products are also often described in the CE literature, sometimes framed as part of product-lifetime extension strategies [53] and sometimes as part of looping strategies [1].

Some additional strategies, not mentioned in the EMF framework [1], can be extracted from literature. Material efficiency in product design is a commonly used strategy to reduce unnecessary resource use [52,53]. Similarly, sustainable design strategies to improve the efficiency of inputs during use are well established, particularly with regards to energy efficiency.

From a broader perspective, a core aspect of circular strategies is to support systemic change towards a more sustainable economy. In the design literature, previous research has produced specific design tools that aim to facilitate systems change. Such tools support designers in applying "whole systems design", considering the complex system around the product or service in order to ensure environmental and societal benefits [53]. Table 3 shows circular strategies described in previous literature, and how we map them to eight main categories: efficiency in use, increased utilization, product lifetime extension, reuse, remanufacturing, recycling, material efficiency, and systems change. 
Table 3. Design and business model strategies for CE.

\begin{tabular}{|c|c|c|c|c|c|c|c|c|c|}
\hline \multirow[b]{2}{*}{ Source } & \multirow[b]{2}{*}{ CE Strategy Described } & \multicolumn{8}{|c|}{ Categories of CE Strategies } \\
\hline & & $\begin{array}{l}\text { Efficiency in } \\
\text { Use }\end{array}$ & $\begin{array}{l}\text { Increased } \\
\text { Utilization }\end{array}$ & $\begin{array}{c}\text { Product } \\
\text { Lifetime } \\
\text { Extension }\end{array}$ & Reuse & Remanufacturing & Recycling & $\begin{array}{l}\text { Material } \\
\text { Efficiency }\end{array}$ & $\begin{array}{l}\text { Systems } \\
\text { Change }\end{array}$ \\
\hline \multirow{5}{*}{$\begin{array}{l}\text { Ellen MacArthur } \\
\text { foundation [1] }\end{array}$} & Share & & $\mathrm{x}$ & & & & & & \\
\hline & Maintain/prolong & & & $\mathrm{x}$ & & & & & \\
\hline & Reuse/redistribute & & & & $x$ & & & & \\
\hline & Refurbish/remanufacture & & & & & $\mathrm{x}$ & & & \\
\hline & Recycle & & & & & & $\mathrm{x}$ & & \\
\hline \multirow{3}{*}{ Bocken et al. [4] } & Long-life products & & & $\mathrm{x}$ & & & & & \\
\hline & Product life extension & & & $\mathrm{x}$ & & $\mathrm{x}$ & & & \\
\hline & Closing resource flows & & & & & & $\mathrm{x}$ & & \\
\hline \multirow{6}{*}{ Bakker et al. [52] } & Material efficiency & & & & & & & $x$ & \\
\hline & Longer product life & & & $\mathrm{x}$ & & & & & \\
\hline & Product repair & & & $\mathrm{x}$ & & & & & \\
\hline & Product refurbishment & & & & $\mathrm{x}$ & $\mathrm{x}$ & & & \\
\hline & Product remanufacturing & & & & & $\mathrm{x}$ & & & \\
\hline & Product/material recycling & & & & & & $\mathrm{x}$ & & \\
\hline
\end{tabular}


Table 3. Cont.

\begin{tabular}{|c|c|c|c|c|c|c|c|c|c|}
\hline \multirow[b]{2}{*}{ Source } & \multirow[b]{2}{*}{ CE Strategy Described } & \multicolumn{8}{|c|}{ Categories of CE Strategies } \\
\hline & & $\begin{array}{l}\text { Efficiency in } \\
\text { Use }\end{array}$ & $\begin{array}{l}\text { Increased } \\
\text { Utilization }\end{array}$ & $\begin{array}{c}\text { Product } \\
\text { Lifetime } \\
\text { Extension }\end{array}$ & Reuse & Remanufacturing & Recycling & $\begin{array}{c}\text { Material } \\
\text { Efficiency }\end{array}$ & $\begin{array}{l}\text { Systems } \\
\text { Change }\end{array}$ \\
\hline \multirow{8}{*}{ Balkenendet al. [3] } & Durability & & & $\mathrm{x}$ & & & & & \\
\hline & Upgrading & & & $\mathrm{x}$ & & & & & \\
\hline & Adapting & & & $\mathrm{x}$ & & & & & \\
\hline & Repair & & & $\mathrm{x}$ & & & & & \\
\hline & Refurbishment & & & $\mathrm{x}$ & & $\mathrm{x}$ & & & \\
\hline & Parts harvesting & & & & $\mathrm{x}$ & $\mathrm{x}$ & & & \\
\hline & Remanufacturing & & & & & $\mathrm{x}$ & & & \\
\hline & Recycling & & & & & & $\mathrm{x}$ & & \\
\hline \multirow{4}{*}{ Moreno et al. [53] } & Design for resource conservation & $\mathrm{x}$ & & & & & & $\mathrm{x}$ & \\
\hline & Design for multiple cycles & & & & & $\mathrm{x}$ & $\mathrm{x}$ & & \\
\hline & $\begin{array}{l}\text { Design for long life use of } \\
\text { products }\end{array}$ & & & $\mathrm{x}$ & $\mathrm{x}$ & & & & \\
\hline & Design for systems change & & & & & & & & $\mathrm{x}$ \\
\hline \multirow{4}{*}{$\begin{array}{c}\text { den Hollander et al. } \\
\text { [51] }\end{array}$} & Design for long use & & & $\mathrm{x}$ & & & & & \\
\hline & Design for extended use & & & $\mathrm{x}$ & & & & & \\
\hline & Design for recovery & & & & & $x$ & & & \\
\hline & Design for recycling & & & & & & $x$ & & \\
\hline
\end{tabular}




\subsubsection{Categories Selected}

We select six categories of circular strategies to be used in our framework: efficiency in use, increased utilization, product lifetime extension, reuse, remanufacturing, and recycling (Table 4).

Table 4. Circular strategies used in the framework

\begin{tabular}{cc}
\hline Circular Strategy & Definition as Used in this Paper \\
\hline Efficiency in use & $\begin{array}{c}\text { Energy, water, and other inputs are used more } \\
\text { efficiently during a product's use phase. }\end{array}$ \\
\hline Increased utilization & $\begin{array}{c}\text { Time periods during which a product is not used by } \\
\text { anyone are identified and reduced. }\end{array}$ \\
\hline Reuse & $\begin{array}{c}\text { A product's lifetime is extended by minimizing wear, } \\
\text { through predictive, preventive or reactive } \\
\text { maintenance and repair, or through updates. }\end{array}$ \\
\hline Remanufacturing & $\begin{array}{c}\text { A product or component is identified, assessed and } \\
\text { transferred from one user to another. The process can } \\
\text { involve maintenance steps, such as cleaning. }\end{array}$ \\
\hline Recycling & $\begin{array}{c}\text { A product is inspected and treated to restore its } \\
\text { original functionality, as a preparation for the next } \\
\text { use cycle. The process can include reparations and } \\
\text { replacements of worn parts. }\end{array}$ \\
\hline
\end{tabular}

Compared to Table 3, we exclude material efficiency and systems change. The reason to exclude material efficiency, is that this strategy can only be applied in the design phase, making it less relevant from an IoT point of view. Once the product design is defined, the material efficiency in set. This differs from, for example, efficiency in use, which depends on the product design as well as use patterns and conditions in the product's environment. In this case, IoT derived product-in-use data could thus be used to optimize the efficiency in use during the product's lifetime.

Furthermore, we exclude strategies related to systems change. The reason for this is that systems change is an overarching strategy with a primary focus on impact. We argue that circular systems change related to physical products is always the result of the application of one or more of the other circular strategies. Thus, while we note the importance of understanding system-level effects when designing for the circular economy, a categorization of cases according to their systemic impact is outside the scope of this paper.

\subsection{Final Framework}

Building on the IoT capabilities and the circular strategies derived from literature, we propose a framework composed as a matrix in which the categories of IoT capabilities and circular strategies form the columns and rows respectively. Each combination of IoT capability and circular strategy forms a IoT-CE cross-section (Figure 3). The IoT capabilities in the framework are defined in Table 2. Tracking relates to the ability to uniquely identify and localize assets. Monitoring describes the use of sensors and metering devices to give information about a product's use, condition, and environment. Control makes it possible to steer product operations through some type of digital interface. Optimization relates to goal-based improvement using advanced algorithms as well as monitoring and/or control capabilities. Optimization can be applied to multiple levels. It can refer to adapting product-internal operations, system operations, or service operations such as maintenance. Finally, design evolution is the ability to learn from product-in-use data in order to improve the design of a product or a service. We note that this capability is different from the others in the way that it 
does not necessarily change the functionality of the product itself. Instead, it allows for learning about in-the-field product parameters, such as performance and use patterns. These insights can then be used in the design of a next generation of the product or PSS, rather than during use.

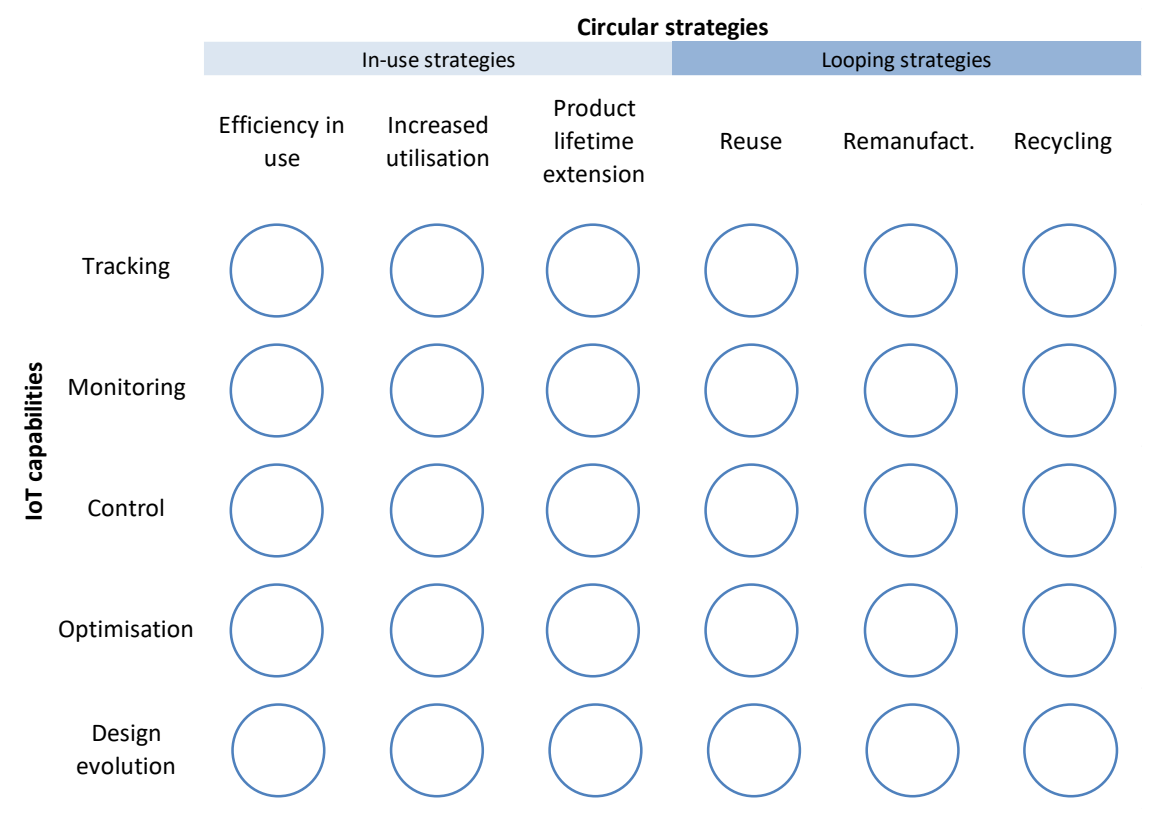

Figure 3. Framework categorizing IoT capabilities on the one hand, and circular strategies on the other.

The circular strategies in the framework are defined in Table 4. The first three strategies relate to the use phase of a product while the last three consider strategies in which products, parts and materials are looped from one use phase to the next. We use the term 'product lifetime extension' to describe activities or design consideration that minimize product wear, or that support maintenance, repair and/or updates. Compared to some other authors, we view reuse strategies as separate from product lifetime extension.

\section{Mapping the Cases to the Framework}

The 40 analyzed cases cover a wide range of products and industries, targeting different customer groups. High-investment products such as mining equipment, wind turbines, and jet engines are examples of products represented in the cases. Moreover, assets in the built environment, infrastructure and the power grid are represented, as are smart connected cars used in different types of car sharing services. Several cases describe solutions for energy management in buildings through smart products such as thermostats, fans, HVAC systems, elevators, washing machines, and lighting systems. Printers and ATM machines are also represented. Most of the identified cases show products and services offered in a business-to-business context, but business-to-customer and business-to-government examples are also present in the set. All cases concern products that can be looped through the technical cycle [49], i.e., that have the potential to be recovered and reused through several life cycles.

Figure 4 shows the mapping of the 40 company cases to the framework. Each case was analyzed and mapped according to the categories of IoT capabilities and circular strategies defined in Section 4, resulting in a 'heat map' of the occurrences of IoT-CE cross-sections. Many of the cases describe more than one IoT-CE cross-section, leading to 150 categorized occurrences of IoT-CE cross-sections from the 40 cases. It should further be noted that while the categories are uniquely defined, they are not mutually exclusive. For example, cases displaying optimization often also rely on the use of monitoring or control capabilities. The results show that examples of IoT-enabled 'efficiency in use' and 'product lifetime extension' dominate in the analyzed set of cases, while IoT-enabled looping and design evolution are relatively unexplored. 


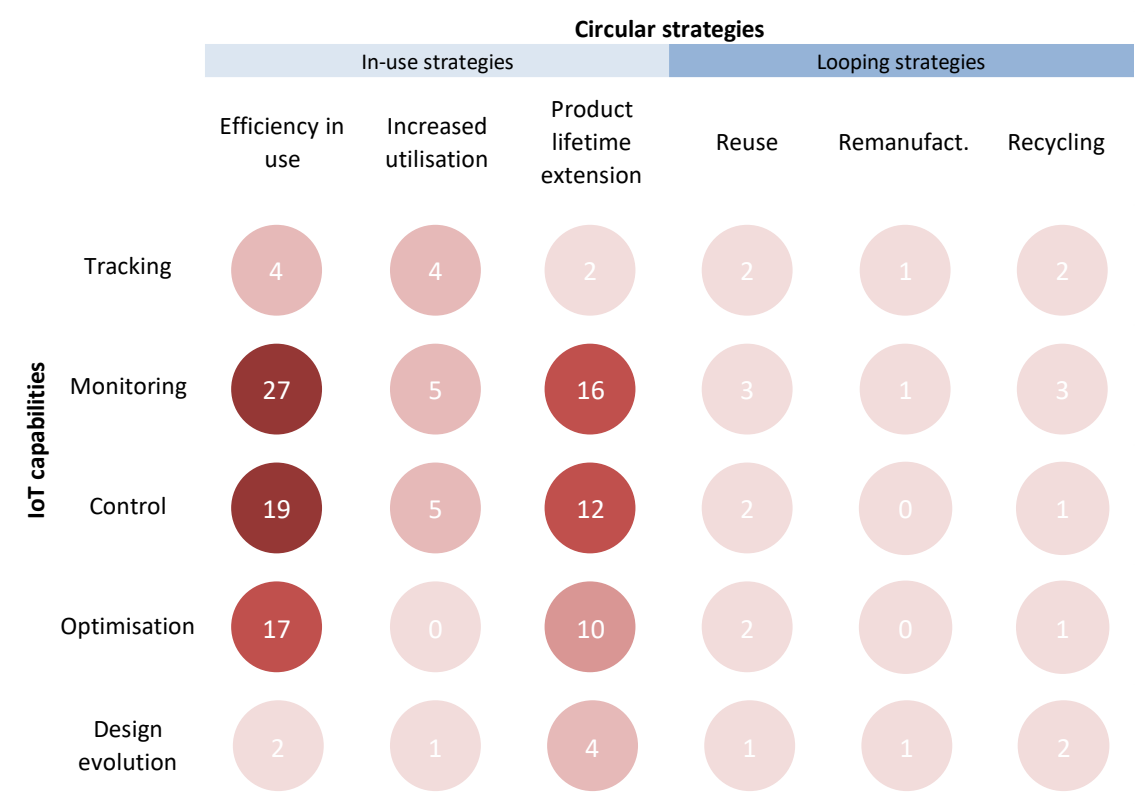

Figure 4. Heat map of the IoT-CE cross-section occurrences found in the 40 analyzed cases.

Below, we present examples of cases which were mapped to different parts of the framework. To facilitate reading, the framework is divided into five sections: (A) IoT-enabled efficiency in use, (B) IoT-enabled increased utilization, (C) IoT-enabled product lifetime extension, (D) IoT-enabled looping, and (E) design evolution for circular strategies (Figure 5). A complete overview of all analyzed cases is provided in Appendix A.

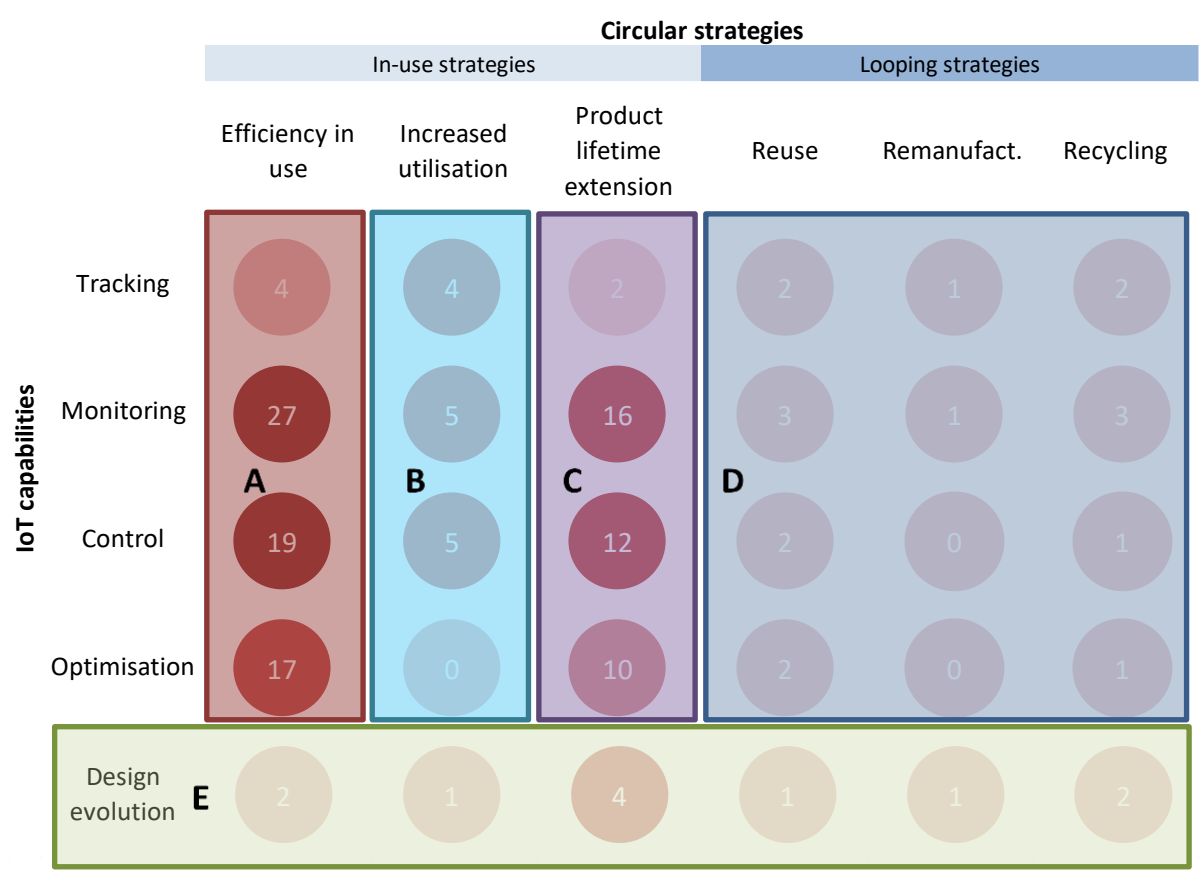

Figure 5. The five sections of the framework: (A) IoT-enabled efficiency in use, (B) IoT-enabled increased utilization, (C) IoT-enabled product lifetime extension, (D) IoT-enabled looping, and (E) design evolution for circular strategies.

\section{IoT-Enabled Efficiency in Use}

The cases in this group display the use of IoT for different types of efficiency measures in the use phase. Many examples describe strategies for saving energy, for example through tracking of 
vehicles, or by monitoring energy use and performance. Moreover, remote control of energy consuming products allows users to save energy, while advanced energy management systems can learn from the user's routines to optimize the system for efficiency and comfort. Another example is that smart farming systems can reduce water use for irrigation. Typical examples are presented in Table 5.

Table 5. Typical examples of cases that describe IoT-enabled efficiency in use

\begin{tabular}{|c|c|}
\hline IoT Capability & $\begin{array}{l}\text { Examples of use of IoT Capability for 'Efficiency in } \\
\text { Use' }\end{array}$ \\
\hline Tracking & $\begin{array}{l}\text { Spire tracks vehicles using satellite technology. } \\
\text { Among other things, the information can be } \\
\text { used by the customer to optimize routing. }\end{array}$ \\
\hline Monitoring & $\begin{array}{l}\text { - Cisco Energy Management uses IoT to measure } \\
\text { energy use and displays it to the user, so that } \\
\text { actions can be taken to improve } \\
\text { operational efficiency. } \\
\text { Libelium allows farmers to monitor their crops' } \\
\text { condition, to better know how much pesticides, } \\
\text { fertilizers, and water is needed. }\end{array}$ \\
\hline Control & $\begin{array}{l}\text { - Carrier systems' system for heating, ventilation, } \\
\text { and air conditioning allows users to control the } \\
\text { indoor climate in a building remotely, so that } \\
\text { energy can be saved when nobody is present. } \\
\text { - Auscott limited control irrigation systems based } \\
\text { on soil moisture data, reducing excess water use. }\end{array}$ \\
\hline Optimization & $\begin{array}{l}\text { - Nest Labs' smart thermostats can adapt the } \\
\text { system operations to the users' routines. In this } \\
\text { way, an optimal balance between comfort and } \\
\text { energy savings can be found. } \\
\text { AGCO Agcommand monitors use, condition of } \\
\text { farm equipment, as well as environmental } \\
\text { parameters, to optimize overall } \\
\text { farm performance. }\end{array}$ \\
\hline
\end{tabular}

IoT-Enabled Increased Utilization

Several cases in this group describe services that allow users to access and use products that they do not own. For example, in a car-sharing service, IoT allows users to find a car that are close and available for use. The service provider can store information about who has used the car, for how long, and at what time. Another example is increased utilization of space in office buildings, allowing fewer rooms to serve more people. Some typical examples are listed in Table 6. 
Table 6. Typical examples of cases that describe IoT-enabled increased utilization

\begin{tabular}{cl}
\hline IoT Capability & $\begin{array}{c}\text { Examples of Use of IoT Capability for 'Increased } \\
\text { Utilization' }\end{array}$ \\
\hline Tracking & $\begin{array}{l}\text { DriveNow and Car2Go offer car sharing } \\
\text { through mobile applications that let users find } \\
\text { available cars based on location. }\end{array}$ \\
- & $\begin{array}{l}\text { ZipCar recover lost or stolen cars (from their car } \\
\text { sharing fleet), and provide facts for insurance } \\
\text { claims if an accident happens. }\end{array}$ \\
\hline Monitoring & $\begin{array}{l}\text { Cisco's "Smart+Connected Personalised Spaces" } \\
\text { office management system aims at increasing } \\
\text { the utilization of office spaces based on } \\
\text { occupancy data. }\end{array}$ \\
\hline Control & $\begin{array}{l}\text { Some level of control is needed in car/bike } \\
\text { sharing systems (e.g., Car2Go, Zipcar, } \\
\text { DriveNow, Hubway) in order to unlock the } \\
\text { product without a physical key. }\end{array}$ \\
\hline
\end{tabular}

\section{IoT-Enabled product Lifetime Extension}

Cases in this group describe maintenance and repair activities, as well as upgrades (see Table 7). For example, tracking allows maintenance actors to identify and locate products that need to be serviced. Moreover, products can monitor their own use and status, and send alerts about when they need maintenance, and which spare parts to order. The capability of control can also enable remote maintenance, repair, and upgrades. In advanced cases, companies continuously monitor the condition of products and apply prediction models that allow them to optimally plan and execute maintenance before a product fails.

Table 7. Typical examples of cases that describe IoT-enabled product lifetime extension.

\begin{tabular}{cl}
\hline IoT Capability & $\begin{array}{c}\text { Examples of Use of IoT Capability for 'Product } \\
\text { Lifetime Extension' }\end{array}$ \\
\hline Tracking & $\begin{array}{l}\text { Philips' 'CityTouch' tracks products and parts } \\
\text { installed at customer sites, facilitating } \\
\text { maintenance activities. }\end{array}$ \\
\hline Monitoring & $\begin{array}{l}\text { Whirlpool's washing machines give the user } \\
\text { notifications about upcoming } \\
\text { maintenance needs. } \\
\text { Philips' 'light-as-a-service' offering includes } \\
\text { monitoring of faults, which is used to manage } \\
\text { maintenance and repairs. }\end{array}$ \\
\hline Control & $\begin{array}{l}\text { Diebold monitors its ATM machines and applies } \\
\text { remote repairs and updates. } \\
\text { Tesla's cars can schedule their own repairs based } \\
\text { on fault monitoring. Tesla also performs remote } \\
\text { service and upgrades on their cars. }\end{array}$ \\
\hline
\end{tabular}


Table 7. Cont.

\begin{tabular}{ll}
\hline IoT Capability & $\begin{array}{c}\text { Examples of Use of IoT Capability for 'Product } \\
\text { Lifetime Extension' }\end{array}$ \\
\hline Optimization & $\begin{array}{l}\text { GE aviation uses hundreds of sensors to identify } \\
\text { discrepancies between expected and actual } \\
\text { performance of jet engines in use, in order to } \\
\text { optimize repair and maintenance services. } \\
\text { Joy Global monitors the performance and faults } \\
\text { of mining machines and uses this data for } \\
\text { predictive maintenance. }\end{array}$ \\
\hline
\end{tabular}

\section{IoT-Enabled Looping}

Only a few cases describe IoT-enabled looping strategies. As summarized in Table 8, tracking of products in the field can give companies a better overview of the installed base of products that will eventually become available for reuse. By monitoring the use and condition of a product, reuse of products can be enabled. The capability of control can also make take-back systems more effective. Finally, the Philips CityTouch case suggests that the manufacturer, by monitoring the condition of products and parts, can optimize the use times in multiple use cycles on the individual part level.

Table 8. Examples of cases that describe IoT-enabled looping.

\begin{tabular}{cl}
\hline IoT Capability & Examples of Use of IoT Capability for 'Looping' \\
\hline Tracking & $\begin{array}{l}\text { Delta Development leases and tracks elevators } \\
\text { in two recent development projects, and can } \\
\text { identify elevators that could be reused in } \\
\text { a different setting. }\end{array}$ \\
\hline Monitoring & $\begin{array}{l}\text { Delta Development monitors the condition of } \\
\text { elevators in use, to assess if they can be } \\
\text { used again. }\end{array}$ \\
\hline Control & $\begin{array}{l}\text { HP's printers monitor ink levels and } \\
\text { automatically order a new cartridge and, at the } \\
\text { same time, an envelope to send the old } \\
\text { cartridge back. }\end{array}$ \\
\hline Optimization & $\begin{array}{l}\text { Philips' 'CityTouch' can monitor the use cycles } \\
\text { of individual luminaires and their constituent } \\
\text { parts which enables looping of components } \\
\text { through additional use cycles. }\end{array}$ \\
\hline
\end{tabular}

Circular Strategies Enabled by Design Evolution

As for IoT-enabled looping strategies, only a few cases described examples of how design evolution could enable circular strategies. However, some examples (shown in Table 9) describe how designers could improve product design based on information about the performance of products in the field. For example, in order to improve design both by avoiding technical failures, and by designing products and services that users value over time, designers could use detailed information about how products are used and discarded. 
Table 9. Examples of cases that describe design evolution for circular strategies.

\begin{tabular}{|c|c|}
\hline CE Strategy & $\begin{array}{c}\text { Example of Use of 'Design Evolution' for Circular } \\
\text { Strategy }\end{array}$ \\
\hline Efficiency in use & $\begin{array}{l}\text { - GE uses data from jet engines in use to support } \\
\text { design improvement of the engine for optimal } \\
\text { performance, including energy efficiency. }\end{array}$ \\
\hline Increased utilization & $\begin{array}{l}\text { - ZipCar uses data about how vehicles are being } \\
\text { used in order to improve their service design to } \\
\text { achieve better availability as well as reduce } \\
\text { operational costs. }\end{array}$ \\
\hline Product lifetime extension & $\begin{array}{l}\text { In HP's 'instant ink service', data from } \\
\text { products-in-use supports design for durability. }\end{array}$ \\
\hline Looping & $\begin{array}{l}\text { The IBM 'reuse optimization tool' uses IoT data } \\
\text { to support the design of services related to } \\
\text { recovery strategies. The tool enables individual } \\
\text { businesses to build a business case for looping. }\end{array}$ \\
\hline
\end{tabular}

\section{Discussion}

The aim of this study was to answer the following research question: How have companies to date implemented IoT for circular strategies and how are these implementations distributed between the opportunities described in literature? As a first step to answer this question, a framework was developed which enabled the mapping of a large set of company cases according to the IoT capabilities used as part of particular circular strategies. The framework distinguishes between five types of IoT capabilities (tracking, monitoring, control, optimization, and design evolution) and six types of circular strategies (efficiency in use, increase utilization, product lifetime extension, reuse, remanufacturing, and recycling). The types of IoT-enabled circular approaches depicted in our framework are largely similar to approaches in previously published work $[19,38]$. However, some differences can be noted. The framework in [19] defines five distinct IoT-enabled circular strategies: smart use, smart maintenance, smart reuse, smart remanufacturing, and smart recycling. The framework in [38] presents eight IoT-enabled circular strategies related to products activity, technical support, preventive and predictive maintenance, product usage, upgrading, and end-of-life activities. However, neither of the two frameworks clearly distinguishes between different types of IoT capabilities used. In comparison, our categorization into six circular strategies and five IoT capabilities provides additional detail into how IoT could support circularity. The categorization of IoT capabilities into tracking, monitoring, control, optimization, and design evolution is useful in that it clarifies different ways in which IoT can be used, and in this study we further noted that the IoT capabilities are linked to each other. Tracking and monitoring can be used as stand-alone strategies, but also as a foundation for control, optimization, and/or design evolution strategies.

Our framework is also different from $[19,38]$, in that it was designed to allow for easy mapping of a wide range of cases according to the IoT-enabled strategies implemented. Through further evaluation with practitioners, the framework could be developed into a tool for companies to map their current state of IoT-enabled CE implementation, and to consider additional opportunities that might be interesting for further exploration.

The second result of the paper is the mapping of 40 cases onto the framework. By analyzing and mapping the cases, we presented concrete examples of cases displaying the different IoT-enabled circular 
strategies. In response to the main research question posed, we observe that current implementations of IoT-enabled circular strategies are mainly applied in the use phase of products (Sections A, B, and C in Figure 5) and that only a few cases have implemented IoT-enabled reuse, remanufacturing, and recycling (Section D in Figure 5). This is an important finding, since reuse, remanufacturing and recycling are often seen as core strategies of the circular economy. Whilst literature has mentioned that IoT can support reuse, remanufacturing, and recycling (e.g., $[25,28]$ ), the results presented here show that real-world applications in these areas are still limited. This result is in line with [19], who stated that smart use and smart maintenance are more common than smart reuse, smart remanufacturing, and smart recycling. However, the analysis used to derive that conclusion is not clear in [19]. In this paper, we systematically derived the implementation distribution between the different strategies, based on the analysis of a large set of cases from practice.

Based on our results, we further note that the capability of design evolution-the feedback of product-in-use data to design in order to improve products and services (E in Figure 5)-is not commonly used in practice to support circular strategies. To the best of our knowledge, this result has not been reported previously.

By pointing out underexplored areas, the findings in this paper provide a starting point for future research into why IoT-enabled looping and design evolution for circular strategies are not implemented to scale. We suggest future research into the real-world challenges of implementing circular looping strategies, and the opportunities and challenges of using IoT technology to support such strategies and associated business models.

Finally, some limitations of the paper in terms of scope and methodology should be mentioned. In this study, we intentionally focused on reviewing implemented solutions, i.e., solutions that are currently offered to customers. Therefore, we excluded prototypes and start-up companies from the analysis. Analyzing such early stage initiatives would enrich the picture with possible future developments in the implementation of IoT-enabled circular strategies.

Moreover, actual assessment of impact on environmental sustainability was outside the scope of this paper. In order for practitioners to be able to effectively use our framework as a tool when innovating on IoT-enabled circular strategies, it should be complemented with other tools that provide information on the sustainability impact of IoT-enabled circular solution.

From a methodology point of view, our study is limited in that it is based on two reports to source the company cases. Although the 40 selected cases include a diverse range of companies and products, it is possible that some relevant examples were not covered in the set. Thus, while the results presented in this paper answer the research question posed in Section 1 by presenting the distribution of implementations in the 40 cases, future studies could include additional cases in order increase the robustness of the results.

Also, the mapping of the cases to the framework unavoidably involved a degree of interpretation. However, we argue that although some cases could have been interpreted differently, it would not notably change the main result-i.e., the relative distribution in the implementation of the different IoT-enabled circular strategies. Also, as we show how we categorize each case (Appendix A), it is possible for other researchers to analyze the same set of cases and potentially come up with an alternative categorization.

Lastly, the rapid literature review approach followed when developing the framework is limited in that it is less comprehensive than a full 'systematic literature review'. However, the goal of this review was not to compile a comprehensive list of publications in the fields of IoT and CE, but to identify commonly agreed views among scholars on IoT capabilities and circular strategies, respectively. Among the criteria used for selecting papers to include in the rapid literature review, one was to omit papers with few citations. This criterion was chosen since a high number of citations was considered a suitable indication that the results were accepted and acknowledged by the scientific community. It is possible, however, that this led to the exclusion of relevant articles that have only recently been published, and therefore lack citations at this point in time. 


\section{Conclusions}

This study aimed to understand how companies have implemented IoT for circular strategies, and how those implementations compare to anticipated opportunities described in literature. To that end, a two-step approach was followed. First, a framework was develop based on previous literature. The framework gives a categorization of IoT-enabled circular strategies according to the IoT capabilities used, and the circular strategies enabled. The framework complements previously published frameworks, as it adds additional detail and allows for easy mapping of diverse cases. In its current form, the framework could be useful for companies since it provides an overview of IoT-enabled circular strategies. However, the usefulness of the framework for practitioners has not been evaluated in this paper.

Secondly, we collected 40 cases from practice depicting current implementation of IoT for CE, and mapped them to the framework. This way, we could provide concrete examples of cases mapped to different parts of the framework, and derive practice-based insights about the current distribution of implementation of IoT-enabled circular strategies.

Our results show that current implementation of IoT-enabled circular strategies mainly supports 'efficiency in use' and 'product lifetime extension'. Only a small number of the reviewed cases displayed IoT-enabled 'looping' (reuse, remanufacturing, and recycling). This is a notable result, as 'closing the loop' is one of the main goals expressed in the CE literature. Moreover, few cases described 'design evolution' for CE, i.e., using the feedback of data from products-in-use to improve circular design.

Future research could build on the results presented in this paper to develop a tool for companies to map their current state of IoT-enabled CE implementation, and to improve their strategy further. To be able to provide such guidance for practitioners, more studies are needed. Specifically, future research should investigate why IoT-enabled looping strategies or design evolution for circular strategies have not been implemented to scale. To do so, in-depth case studies with companies would be relevant, as such studies could extract context-specific opportunities as well as implementation barriers perceived by the companies. Moreover, insights from studies focusing on the actual sustainability impact of different IoT-enabled circular strategies would be important as input to recommendations for practitioners about how to reap the benefits of IoT for CE.

Author Contributions: E.I. is the corresponding author of this manuscript. She is the primary author of this manuscript. She was in charge of collecting and analyzing the data, and was the leading author of the paper. E.J. and R.B. supervised her in this process and contributed to the writing process and to reviewing the paper internally. G.K. provided expert knowledge and reviewed the manuscript at different stages of the process. All authors read and approved the final manuscript.

Funding: This work was funded by the Circular European Economy Innovative Training Network, Circ€uit, an action funded by the European Commission under the Horizon 2020 Marie Skłodowska Curie Action 2016 (grant agreement number 721909).

Acknowledgments: The authors would like to express their gratitude towards the anonymous reviewers whose feedback helped improve this manuscript.

Conflicts of Interest: The authors declare no conflict of interest. 


\section{Appendix A}

Table A1. Product/service cases analyzed in this paper and how they were categorized according to IoT capabilities and circular strategies.

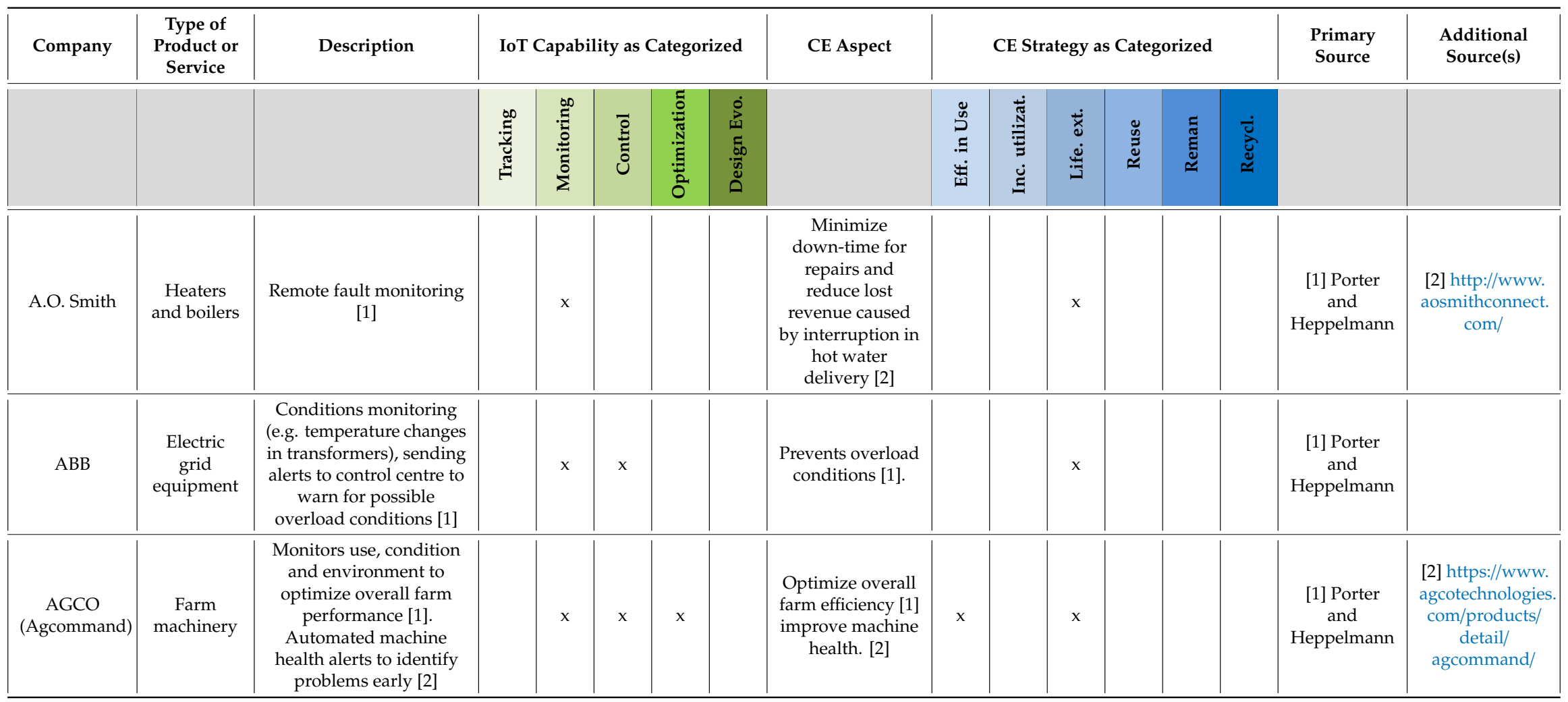


Table A1. Cont.

\begin{tabular}{|c|c|c|c|c|c|c|c|c|c|c|c|c|c|c|c|c|}
\hline \multirow[t]{2}{*}{ Company } & \multirow{2}{*}{$\begin{array}{c}\text { Type of } \\
\text { Product or } \\
\text { Service }\end{array}$} & \multirow[t]{2}{*}{ Description } & \multicolumn{5}{|c|}{ IoT Capability as Categorized } & \multirow[t]{2}{*}{ CE Aspect } & \multicolumn{6}{|c|}{ CE Strategy as Categorized } & \multirow{2}{*}{$\begin{array}{l}\text { Primary } \\
\text { Source }\end{array}$} & \multirow{2}{*}{$\begin{array}{c}\text { Additional } \\
\text { Source(s) }\end{array}$} \\
\hline & & & 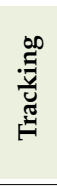 & 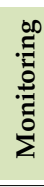 & 总 & 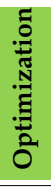 & 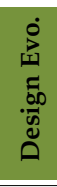 & & 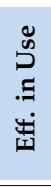 & 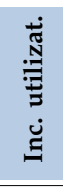 & 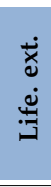 & 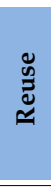 & 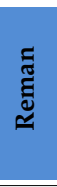 & $\begin{array}{l}\text { हुँ } \\
\text { đ̆ }\end{array}$ & & \\
\hline Arup & Bridge & $\begin{array}{c}\text { Structural health } \\
\text { monitoring systems } \\
\text { which gives warnings of } \\
\text { structural problems, } \\
\text { allows targeted } \\
\text { inspections/interventions } \\
\text { to ensure smooth } \\
\text { operations and prolong } \\
\text { the bridge's service life. } \\
\text { Approximately } 1000 \\
\text { sensors will provide data } \\
\text { of the bridge's condition, } \\
\text { enabling predictive } \\
\text { maintenance. [1] }\end{array}$ & & $\mathrm{x}$ & $\mathrm{x}$ & $\mathrm{x}$ & & $\begin{array}{c}\text { Enables } \\
\text { predictive } \\
\text { maintenance and } \\
\text { prolongs the } \\
\text { bridge's service } \\
\text { life [1] }\end{array}$ & & & $\mathrm{x}$ & & & & [1] EMF & $\begin{array}{c}\text { https: } \\
\text { //www.arup. } \\
\text { com/projects/q/ } \\
\text { queensferry- } \\
\text { crossing }\end{array}$ \\
\hline
\end{tabular}


Table A1. Cont.

\begin{tabular}{|c|c|c|c|c|c|c|c|c|c|c|c|c|c|c|c|c|}
\hline \multirow[t]{2}{*}{ Company } & \multirow{2}{*}{$\begin{array}{c}\text { Type of } \\
\text { Product or } \\
\text { Service } \\
\end{array}$} & \multirow[t]{2}{*}{ Description } & \multicolumn{5}{|c|}{ IoT Capability as Categorized } & \multirow[t]{2}{*}{ CE Aspect } & \multicolumn{6}{|c|}{ CE Strategy as Categorized } & \multirow{2}{*}{$\begin{array}{l}\text { Primary } \\
\text { Source }\end{array}$} & \multirow{2}{*}{$\begin{array}{c}\text { Additional } \\
\text { Source(s) }\end{array}$} \\
\hline & & & 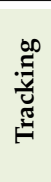 & 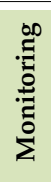 & 总 & 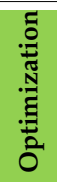 & 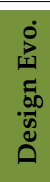 & & 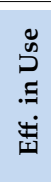 & 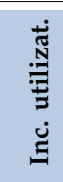 & 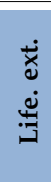 & 苞 & 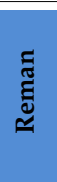 & 节 & & \\
\hline Big Ass & Ceiling fans & $\begin{array}{l}\text { Fans regulate speed on } \\
\text { basis of temperature and } \\
\text { humidity [1]. Works with } \\
\text { air conditioning system } \\
\text { to make them more } \\
\text { effective [2] }\end{array}$ & & $\mathrm{x}$ & $\mathrm{x}$ & & & $\begin{array}{c}\text { By incorporating } \\
\text { Big Ass Fans into } \\
\text { building } \\
\text { automation } \\
\text { systems and } \\
\text { using controls, } \\
\text { energy savings } \\
\text { become easy and } \\
\text { automatic. [2] }\end{array}$ & $\mathrm{x}$ & & & & & & $\begin{array}{l}\text { [1] Porter } \\
\text { and } \\
\text { Heppelmann }\end{array}$ & $\begin{array}{c}\text { [2] http://docs. } \\
\text { bigassfans.com/ } \\
\text { ae-files/BAS- } \\
\text { Energy- } \\
\text { Brochure.pdf }\end{array}$ \\
\hline Car2Go & $\begin{array}{c}\text { Car-sharing } \\
\text { service }\end{array}$ & $\begin{array}{l}\text { Car sharing based on } \\
\text { tracking of the car, and } \\
\text { monitoring of the time } \\
\text { the user has used the car. } \\
\text { The user can unlock the } \\
\text { car through the app. }\end{array}$ & $\mathrm{x}$ & $\mathrm{x}$ & $\mathrm{x}$ & & & $\begin{array}{l}\text { A larger number } \\
\text { of people can } \\
\text { reach their } \\
\text { destination with } \\
\text { fewer assets [1] }\end{array}$ & & $\mathrm{x}$ & & & & & [1] EMF & $\begin{array}{c}\text { [2] https://www. } \\
\text { car2go.com/US/ } \\
\text { en/\#152741 } \\
\text { https: } \\
\text { //www.car2go. } \\
\text { com/US/en/faq/ }\end{array}$ \\
\hline $\begin{array}{l}\text { Carrier } \\
\text { Corporation } \\
\text { (Infinity) }\end{array}$ & $\begin{array}{l}\text { HVAC and } \\
\text { building } \\
\text { control }\end{array}$ & $\begin{array}{l}\text { The control knows to } \\
\text { conserve energy while } \\
\text { you are not home. [2] }\end{array}$ & & $\mathrm{x}$ & $\mathrm{x}$ & & & $\begin{array}{c}\text { The } \\
\text { Infinity®System } \\
\text { bundles efficient } \\
\text { performance with } \\
\text { precise energy } \\
\text { reporting. It can } \\
\text { reduce your } \\
\text { utility bills and } \\
\text { increase your } \\
\text { energy savings. } \\
\text { [2] }\end{array}$ & $\mathrm{x}$ & & & & & & $\begin{array}{l}\text { [1] Porter } \\
\text { and } \\
\text { Heppelmann }\end{array}$ & $\begin{array}{l}\text { [2] https://www. } \\
\text { carrier.com/ } \\
\text { residential/en/ } \\
\text { us/innovation/ } \\
\text { \#infinity }\end{array}$ \\
\hline
\end{tabular}


Table A1. Cont.

\begin{tabular}{|c|c|c|c|c|c|c|c|c|c|c|c|c|c|c|c|c|}
\hline \multirow[t]{2}{*}{ Company } & \multirow{2}{*}{$\begin{array}{c}\text { Type of } \\
\text { Product or } \\
\text { Service }\end{array}$} & \multirow[t]{2}{*}{ Description } & \multicolumn{5}{|c|}{ IoT Capability as Categorized } & \multirow[t]{2}{*}{ CE Aspect } & \multicolumn{6}{|c|}{ CE Strategy as Categorized } & \multirow{2}{*}{$\begin{array}{c}\text { Primary } \\
\text { Source }\end{array}$} & \multirow{2}{*}{$\begin{array}{l}\text { Additional } \\
\text { Source(s) }\end{array}$} \\
\hline & & & 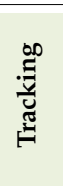 & 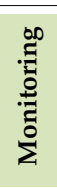 & 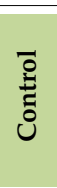 & 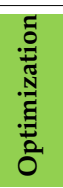 & 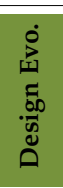 & & $\begin{array}{l}\mathscr{\Xi} \\
\stackrel{\infty}{\Xi} \\
\Xi \\
\dot{\square}\end{array}$ & 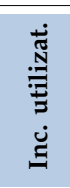 & $\begin{array}{l}\dot{\Delta} \\
\stackrel{\Delta}{\leftrightarrows}\end{array}$ & 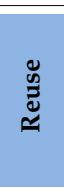 & 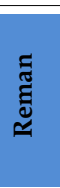 & 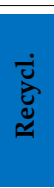 & & \\
\hline Cisco & $\begin{array}{c}\text { Space } \\
\text { management } \\
\text { in real } \\
\text { estate }\end{array}$ & $\begin{array}{l}\text { Real time occupancy } \\
\text { sensing allows for more } \\
\text { intense use of building. } \\
\text { Provides energy } \\
\text { consumption data (e.g. } \\
\text { lights, HVAC, blinds). [1] }\end{array}$ & & $\mathrm{x}$ & & & & $\begin{array}{c}\text { More intense use } \\
\text { of the workspace. } \\
\text { Energy savings. } \\
\text { [1] }\end{array}$ & $\mathrm{x}$ & $\mathrm{x}$ & & & & & [1] EMF & \\
\hline $\begin{array}{l}\text { Cisco Energy } \\
\text { Management } \\
\text { (CEM) }\end{array}$ & $\underset{\substack{\text { Energy } \\
\text { management } \\
\text { system }}}{\mid}$ & $\begin{array}{c}\text { Measure and manage } \\
\text { energy use (and CO2 } \\
\text { emissions) at } \\
\text { manufacturing facility [1] }\end{array}$ & & $\mathrm{x}$ & & & & $\begin{array}{l}\text { Goal of reducing } \\
\text { energy } \\
\text { consumption by } \\
20 \% \text {. [1] }\end{array}$ & $\mathrm{x}$ & & & & & & [1] EMF & \\
\hline $\begin{array}{l}\text { Current } \\
\text { (GE) }\end{array}$ & $\begin{array}{c}\text { Energy } \\
\text { management } \\
\text { system }\end{array}$ & $\begin{array}{l}\text { Integrates data from the } \\
\text { building's systems and } \\
\text { responds in real time [1] }\end{array}$ & & $\mathrm{x}$ & $\mathrm{x}$ & $x$ & & $\begin{array}{l}\text { Deliver energy } \\
\text { savings and } \\
\text { operational } \\
\text { efficiency } \\
\text { improvements. } \\
\text { [2] }\end{array}$ & $\mathrm{x}$ & & & & & & [1] EMF & $\begin{array}{l}\text { [2] https://www. } \\
\text { currentbyge.com/ } \\
\text { offices }\end{array}$ \\
\hline $\begin{array}{c}\text { Delta } \\
\text { Development }\end{array}$ & Elevators & $\begin{array}{l}\text { Conditions monitoring } \\
\text { and optimized } \\
\text { maintenance. IoT data } \\
\text { can help identify } \\
\text { products that can be } \\
\text { reused in a different } \\
\text { setting. [1] }\end{array}$ & & $\mathrm{x}$ & $\mathrm{x}$ & $\mathrm{x}$ & & $\begin{array}{l}\text { Improved } \\
\text { maintenance and } \\
\text { reuse. [1] }\end{array}$ & & & $\mathrm{x}$ & $\mathrm{x}$ & & & [1] EMF & $\begin{array}{l}\text { [2] http://www. } \\
\text { deltadevelopment. } \\
\text { eu/en/ } \\
\text { sustainability }\end{array}$ \\
\hline
\end{tabular}


Table A1. Cont.

\begin{tabular}{|c|c|c|c|c|c|c|c|c|c|c|c|c|c|c|c|c|}
\hline \multirow[t]{2}{*}{ Company } & \multirow{2}{*}{\begin{tabular}{|c|} 
Type of \\
Product or \\
Service
\end{tabular}} & \multirow[t]{2}{*}{ Description } & \multicolumn{5}{|c|}{ IoT Capability as Categorized } & \multirow[t]{2}{*}{ CE Aspect } & \multicolumn{6}{|c|}{ CE Strategy as Categorized } & \multirow[t]{2}{*}{$\begin{array}{l}\text { Primary } \\
\text { Source }\end{array}$} & \multirow[t]{2}{*}{ Additional Source(s) } \\
\hline & & & 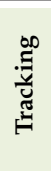 & 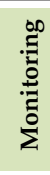 & 咅 & 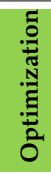 & 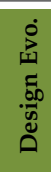 & & 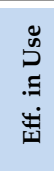 & 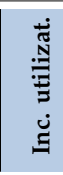 & 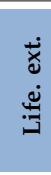 & $\underset{\mathscr{\Xi}}{\tilde{\Xi}}$ & ๕్ & 芯 & & \\
\hline Diebold & ATM & $\begin{array}{l}\text { Status monitoring and } \\
\text { analysis. Machine can be } \\
\text { serviced remotely [2] or } \\
\text { the company deploys a } \\
\text { technician who has been } \\
\text { given a detailed } \\
\text { diagnosis of the problem, } \\
\text { a recommended repair } \\
\text { process, and, often, the } \\
\text { needed parts. Remote } \\
\text { updates. [1] }\end{array}$ & & $\mathrm{x}$ & $x$ & & & $\begin{array}{c}\text { Fault detection, } \\
\text { remote service. } \\
\text { Informed repairs. } \\
\text { Remote updates. } \\
{[1]}\end{array}$ & & & $x$ & & & & $\begin{array}{c}\text { [1] Porter } \\
\text { and } \\
\text { Heppelmann }\end{array}$ & $\begin{array}{l}\text { [2] http://www.s4growth.com/ } \\
\text { publications/whitepapers/ } \\
\text { dieboldwhitepaper.pdf }\end{array}$ \\
\hline DriveNow & Car sharing & $\begin{array}{l}\text { Tracks location of cars. } \\
\text { User can access the car } \\
\text { through the app. Price } \\
\text { based on the time the } \\
\text { user uses the car. }\end{array}$ & $\mathrm{x}$ & $x$ & $\mathrm{x}$ & & & $\begin{array}{l}\text { A larger number } \\
\text { of people can } \\
\text { reach their } \\
\text { destination with } \\
\text { fewer assets. [1] }\end{array}$ & & $x$ & & & & & $\begin{array}{l}\text { [1] EMF [2] } \\
\text { Porter and } \\
\text { Heppelmann }\end{array}$ & $\begin{array}{l}\text { [3] https://www.drive-now.com/ } \\
\text { gb/en/london }\end{array}$ \\
\hline Enevo & Smart bin & $\begin{array}{l}\text { Automatically generated } \\
\text { schedules and optimized } \\
\text { routes taking into } \\
\text { account future fill level } \\
\text { projections, truck } \\
\text { availability, traffic } \\
\text { information, road } \\
\text { restrictions, container } \\
\text { and content types the } \\
\text { vehicle can collect etc. } \\
\text { New schedules and } \\
\text { routes are planned not } \\
\text { only looking at the } \\
\text { current situation, but } \\
\text { considering the future } \\
\text { outlook as well. [2] }\end{array}$ & & $x$ & & $x$ & & $\begin{array}{c}\text { Collections based } \\
\text { on Enevo's smart } \\
\text { plans significantly } \\
\text { reduces costs, } \\
\text { emissions, road } \\
\text { wear, vehicle } \\
\text { wear, noise } \\
\text { pollution, and } \\
\text { work hours. [2] }\end{array}$ & $x$ & & & & & & [1] EMF & $\begin{array}{c}\text { [2] https://www.eiseverywhere. } \\
\text { com/ereg/retrieve_upload.php? } \\
\text { MTI1NTk1NzFfNzE4MjUzNQ= } \\
=\end{array}$ \\
\hline
\end{tabular}


Table A1. Cont.

\begin{tabular}{|c|c|c|c|c|c|c|c|c|c|c|c|c|c|c|c|c|}
\hline \multirow[t]{2}{*}{ Company } & \multirow{2}{*}{$\begin{array}{c}\text { Type of } \\
\text { Product or } \\
\text { Service }\end{array}$} & \multirow[t]{2}{*}{ Description } & \multicolumn{5}{|c|}{ IoT Capability as Categorized } & \multirow[t]{2}{*}{ CE Aspect } & \multicolumn{6}{|c|}{ CE Strategy as Categorized } & \multirow{2}{*}{$\begin{array}{l}\text { Primary } \\
\text { Source }\end{array}$} & \multirow[t]{2}{*}{$\begin{array}{c}\text { Additional } \\
\text { Source(s) }\end{array}$} \\
\hline & & & 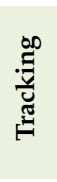 & 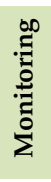 & 总 & 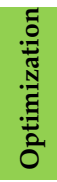 & 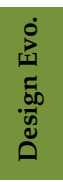 & & 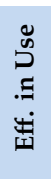 & 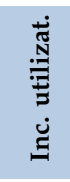 & 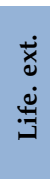 & $\underset{\Xi}{\mathscr{J}}$ & 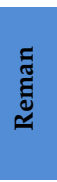 & 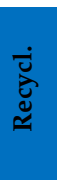 & & \\
\hline Enlighted & $\begin{array}{c}\text { Energy } \\
\text { management } \\
\text { system }\end{array}$ & $\begin{array}{l}\text { IoT- based energy service } \\
\text { system, [1] uses sensor } \\
\text { data about energy, } \\
\text { occupancy and } \\
\text { environment. links to a } \\
\text { lighting control system } \\
\text { and facilitates integration } \\
\text { with third-party building } \\
\text { automation and demand } \\
\text { response systems. [2] }\end{array}$ & & $\mathrm{x}$ & $\mathrm{x}$ & & & $\begin{array}{l}\text { Claim it saves } \\
\text { their clients } \\
60-70 \% \text { on } \\
\text { lighting and } \\
20-30 \% \text { on } \\
\text { heating/cooling } \\
\text { efficiency. [1] }\end{array}$ & $\mathrm{x}$ & & & & & & [1] EMF & $\begin{array}{l}\text { [2] http://www. } \\
\text { enlightedinc. } \\
\text { com/system- } \\
\text { and-solutions/ } \\
\text { iot-system/ } \\
\text { energy- } \\
\text { manager/ }\end{array}$ \\
\hline $\begin{array}{l}\text { GE Aviation } \\
\text { (TrueChoice) }\end{array}$ & Jet engines & $\begin{array}{c}\text { Optimize engine } \\
\text { performance by } \\
\text { identifying discrepancies } \\
\text { between expected and } \\
\text { actual performance [1]. } \\
\text { Remote diagnostics for } \\
\text { minimizing maintenance } \\
\text { while maximizing fleet } \\
\text { efficiency. [3] }\end{array}$ & & $\mathrm{x}$ & & $\mathrm{x}$ & $\mathrm{x}$ & $\begin{array}{l}\text { Insights from } \\
\text { data has resulted } \\
\text { in reduced fuel } \\
\text { use [1], and it } \\
\text { enables efficient } \\
\text { maintenance. [3] }\end{array}$ & $\mathrm{x}$ & & $\mathrm{x}$ & & & & $\begin{array}{l}\text { [1] Porter } \\
\text { and } \\
\text { Heppelmann } \\
\text { [2] EMF }\end{array}$ & $\begin{array}{l}\text { [3] https://www. } \\
\text { geaviation.com/ } \\
\text { commercial/ } \\
\text { truechoice- } \\
\text { commercial- } \\
\text { services/ } \\
\text { truechoice- } \\
\text { flight-hour }\end{array}$ \\
\hline $\begin{array}{l}\text { GE Wind } \\
\text { power }\end{array}$ & $\begin{array}{l}\text { Wind } \\
\text { turbines }\end{array}$ & $\begin{array}{l}\text { Wind turbines that } \\
\text { automatically change } \\
\text { gear according to wind } \\
\text { conditions [1] increases } \\
\text { wind farm's output by up } \\
\text { to } 10 \% \text {, taking into } \\
\text { account environmental } \\
\text { conditions. [3] backed by } \\
\text { data driven insights } \\
\text { through intelligent } \\
\text { monitoring, detection } \\
\text { and diagnostic } \\
\text { capabilities. Specialized } \\
\text { upgrades, repairs, and } \\
\text { exchange techniques to } \\
\text { ensure superior turbine } \\
\text { performance. [2] }\end{array}$ & & $\mathrm{x}$ & $\mathrm{x}$ & $\mathrm{x}$ & & $\begin{array}{c}\text { More power } \\
\text { output (efficiency) } \\
\text { [3] and improved } \\
\text { maintenance [2] }\end{array}$ & $\mathrm{x}$ & & $\mathrm{x}$ & & & & [1] EMF & $\begin{array}{l}\text { [2] https://www. } \\
\text { ge.com/content/ } \\
\text { dam/gepogep- } \\
\text { renewables/ } \\
\text { global/ee_US/ } \\
\text { documents/ } \\
\text { wiwi-services/ } \\
\text { _WindServiWin_- } \\
\text { Brochure.pdf } \\
\text { https: } \\
\text { //www.ge.com/ } \\
\text { renewableenergy/ } \\
\text { wind-energy/ } \\
\text { turbine- } \\
\text { services/ } \\
\text { platform- } \\
\text { upgrades }\end{array}$ \\
\hline
\end{tabular}


Table A1. Cont.

\begin{tabular}{|c|c|c|c|c|c|c|c|c|c|c|c|c|c|c|c|c|}
\hline \multirow[t]{2}{*}{ Company } & \multirow{2}{*}{$\begin{array}{c}\text { Type of } \\
\text { Product or } \\
\text { Service }\end{array}$} & \multirow[t]{2}{*}{ Description } & \multicolumn{5}{|c|}{ IoT Capability as Categorized } & \multirow[t]{2}{*}{ CE Aspect } & \multicolumn{6}{|c|}{ CE Strategy as Categorized } & \multirow[t]{2}{*}{$\begin{array}{c}\text { Primary } \\
\text { Source }\end{array}$} & \multirow[t]{2}{*}{$\begin{array}{c}\text { Additional } \\
\text { Source(s) }\end{array}$} \\
\hline & & & 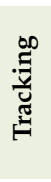 & 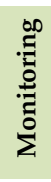 & $\begin{array}{l}\overline{0} \\
\text { हैं } \\
\text { Uे }\end{array}$ & 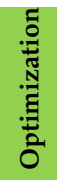 & 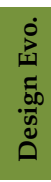 & & 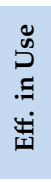 & 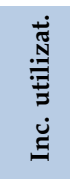 & $\begin{array}{l}\overrightarrow{0} \\
\stackrel{0}{\leftrightarrows} \\
\stackrel{3}{3}\end{array}$ & 节 & 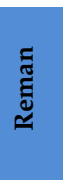 & $\begin{array}{l}\text { गुं } \\
\text { ¿ूँ }\end{array}$ & & \\
\hline $\begin{array}{c}\mathrm{HP} \\
\text { (Instant ink) }\end{array}$ & $\begin{array}{l}\text { Printing as } \\
\text { a service }\end{array}$ & $\begin{array}{l}\text { The printer monitors how } \\
\text { it is being used, as well as } \\
\text { ink levels in the } \\
\text { cartridges. New } \\
\text { cartridges are ordered } \\
\text { automatically, and the } \\
\text { user gets an envelope to } \\
\text { send the used one back } \\
\text { for recycling. Printer use } \\
\text { data helps inform system } \\
\text { designs, and future } \\
\text { product designs, to } \\
\text { improve serviceability, } \\
\text { durability [1] }\end{array}$ & & $\mathrm{x}$ & $x$ & & $x$ & $\begin{array}{l}\text { Cartridge } \\
\text { recycling [2] }\end{array}$ & & & $x$ & & & $x$ & [1] EMF & $\begin{array}{l}\text { [2] http://www. } \\
\text { hp.com/hpinfo/ } \\
\text { globalcitizenship/ } \\
\text { 09gcreport/ } \\
\text { enviro/reuse/ } \\
\text { programs.html }\end{array}$ \\
\hline IBM & $\begin{array}{c}\text { Reuse } \\
\text { optimization } \\
\text { tool }\end{array}$ & $\begin{array}{l}\text { Tracking location and } \\
\text { availability. Conditions } \\
\text { monitoring. Integrates } \\
\text { data about design } \\
\text { specifications, } \\
\text { components list and } \\
\text { materials. Optimization } \\
\text { model to support } \\
\text { decision about recovery } \\
\text { option. Based on these } \\
\text { insight, companies can } \\
\text { build a CE business case } \\
{[1]}\end{array}$ & $\mathrm{x}$ & $\mathrm{x}$ & & & $\mathrm{x}$ & $\begin{array}{l}\text { Optimal reuse } \\
\text { option of a } \\
\text { product can be } \\
\text { made: weather to } \\
\text { refurbish, } \\
\text { remanufacture or } \\
\text { harvest key } \\
\text { components, or } \\
\text { recycle materials. } \\
\text { [1] }\end{array}$ & & & & $\mathrm{x}$ & $\mathrm{x}$ & $\mathrm{x}$ & [1] EMF & \\
\hline
\end{tabular}


Table A1. Cont.

\begin{tabular}{|c|c|c|c|c|c|c|c|c|c|c|c|c|c|c|c|c|}
\hline \multirow[t]{2}{*}{ Company } & \multirow{2}{*}{$\begin{array}{c}\text { Type of } \\
\text { Product or } \\
\text { Service } \\
\end{array}$} & \multirow[t]{2}{*}{ Description } & \multicolumn{5}{|c|}{ IoT Capability as Categorized } & \multirow[t]{2}{*}{ CE Aspect } & \multicolumn{6}{|c|}{ CE Strategy as Categorized } & \multirow[t]{2}{*}{$\begin{array}{l}\text { Primary } \\
\text { Source }\end{array}$} & \multirow[t]{2}{*}{$\begin{array}{c}\text { Additional } \\
\text { Source(s) }\end{array}$} \\
\hline & & & 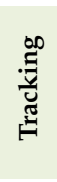 & 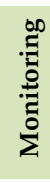 & 苞 & 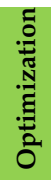 & 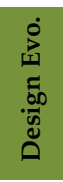 & & 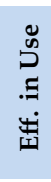 & 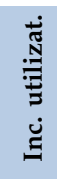 & $\begin{array}{l}\dot{\mathrm{x}} \\
\stackrel{\dot{u}}{\mathrm{u}}\end{array}$ & 苛 & 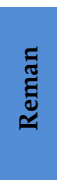 & $\begin{array}{l}\dot{0} \\
\text { हूँ }\end{array}$ & & \\
\hline $\begin{array}{c}\text { JohnDeere } \\
\text { (Farmsight) }\end{array}$ & $\begin{array}{c}\text { Farm } \\
\text { machinery, } \\
\text { irrigation }\end{array}$ & $\begin{array}{c}\text { Monitors yield per } \\
\text { hectare, which can be } \\
\text { used to optimize } \\
\text { irrigation and the use of } \\
\text { fertilizers and pesticides. } \\
\text { Optimize overall farm } \\
\text { performance. }\end{array}$ & & $\mathrm{x}$ & $\mathrm{x}$ & $\mathrm{x}$ & & $\begin{array}{l}\text { Reduced water, } \\
\text { fertilizer, and } \\
\text { pesticide use. [1] }\end{array}$ & $\mathrm{x}$ & & & & & & $\begin{array}{l}\text { [1] Porter and } \\
\text { Heppelmann, } \\
\text { [2] EMF }\end{array}$ & $\begin{array}{c}\text { [3] http:// } \\
\text { smartagservices } \\
\text { jd-dealer.co.uk/ } \\
\text { Services/Smart- } \\
\text { FarmSight }\end{array}$ \\
\hline Joy Global & $\begin{array}{l}\text { Mining } \\
\text { equipment }\end{array}$ & $\begin{array}{l}\text { Machines autonomously } \\
\text { coordinate with other } \\
\text { equipment to improve } \\
\text { mining efficiency. } \\
\text { Monitoring of } \\
\text { performance and faults. } \\
\text { Can be controlled from a } \\
\text { control centre on the } \\
\text { surface. The system can } \\
\text { optimize performance } \\
\text { across the fleet of } \\
\text { equipment in the mine. } \\
\text { [1] }\end{array}$ & & $\mathrm{x}$ & $\mathrm{x}$ & $\mathrm{x}$ & & $\begin{array}{l}\text { Fault detection } \\
\text { and predictive } \\
\text { service indicators } \\
\text { facilitates } \\
\text { maintenance. The } \\
\text { system can } \\
\text { improve mining } \\
\text { efficiency. [1] }\end{array}$ & $\mathrm{x}$ & & $x$ & & & & $\begin{array}{l}\text { [1] Porter } \\
\text { and } \\
\text { Heppelmann }\end{array}$ & \\
\hline Libelium & 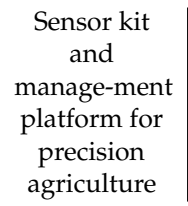 & $\begin{array}{c}\text { Monitoring of } \\
\text { environmental factors } \\
\text { and condition of crops. } \\
{[1]}\end{array}$ & & $\mathrm{x}$ & & & & $\begin{array}{l}\text { Reduce the } \\
\text { amount of } \\
\text { pesticides, } \\
\text { fertilizers and } \\
\text { water used. [1] }\end{array}$ & $\mathrm{x}$ & & & & & & [1] EMF & \\
\hline Nest & Thermo-stats & $\begin{array}{c}\text { Monitors energy use and } \\
\text { energy demand on grid, } \\
\text { can be remotely } \\
\text { controlled, maximizes } \\
\text { comfort while } \\
\text { minimizing energy } \\
\text { consumption [1] }\end{array}$ & & $\mathrm{x}$ & $\mathrm{x}$ & $\mathrm{x}$ & & $\begin{array}{c}\text { Minimize energy } \\
\text { consumption, and } \\
\text { energy use during } \\
\text { peak demand } \\
\text { periods [1] }\end{array}$ & $\mathrm{x}$ & & & & & & $\begin{array}{l}\text { [1] Porter } \\
\text { and } \\
\text { Heppelmann } \\
\text { [2] EMF }\end{array}$ & \\
\hline
\end{tabular}


Table A1. Cont.

\begin{tabular}{|c|c|c|c|c|c|c|c|c|c|c|c|c|c|c|c|c|}
\hline \multirow[t]{2}{*}{ Company } & \multirow{2}{*}{$\begin{array}{c}\text { Type of } \\
\text { Product or } \\
\text { Service }\end{array}$} & \multirow[t]{2}{*}{ Description } & \multicolumn{5}{|c|}{ IoT Capability as Categorized } & \multirow[t]{2}{*}{ CE Aspect } & \multicolumn{6}{|c|}{ CE Strategy as Categorized } & \multirow{2}{*}{$\begin{array}{l}\text { Primary } \\
\text { Source }\end{array}$} & \multirow{2}{*}{$\begin{array}{l}\text { Additional } \\
\text { Source(s) }\end{array}$} \\
\hline & & & 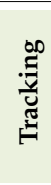 & $\frac{\infty}{\overbrace{0}^{0}}$ & 宽 & 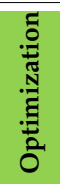 & 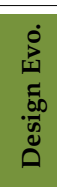 & & 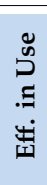 & 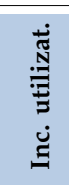 & 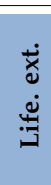 & ֻू & 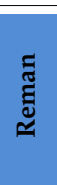 & 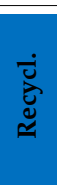 & & \\
\hline $\begin{array}{l}\text { Opower (now } \\
\text { Oracle) }\end{array}$ & $\begin{array}{l}\text { Energy data } \\
\text { management }\end{array}$ & $\begin{array}{l}\text { Stores and analyzes energy } \\
\text { use from smart meters in } \\
\text { cloud platform [2] from which } \\
\text { energy reports can be written. } \\
\text { [1] }\end{array}$ & & $\mathrm{x}$ & & & & $\begin{array}{c}\text { Incentivizing } \\
\text { users to reduce } \\
\text { their energy bill. } \\
\text { [1] }\end{array}$ & $\mathrm{x}$ & & & & & & [1] EMF & $\begin{array}{c}\text { [2] https://www. } \\
\text { oracle.com/se/ } \\
\text { corporate/ } \\
\text { acquisitions/ } \\
\text { opower/index. } \\
\text { html }\end{array}$ \\
\hline $\begin{array}{c}\text { Philips } \\
\text { light-as-a-service }\end{array}$ & Lighting & $\begin{array}{l}\text { Optimizes power } \\
\text { consumption based on live } \\
\text { data of use patterns. Checks } \\
\text { system operations and } \\
\text { monitors faults. [1] }\end{array}$ & & $\mathrm{x}$ & $\mathrm{x}$ & $\mathrm{x}$ & & $\begin{array}{c}\text { Lower power } \\
\text { consumption [1]. } \\
\text { Manage all } \\
\text { maintenance and } \\
\text { repair work, } \\
\text { optimize the } \\
\text { installation's } \\
\text { performance } \\
\text { throughout the } \\
\text { life of the contract. } \\
\text { [2] }\end{array}$ & $\mathrm{x}$ & & $\mathrm{x}$ & & & & [1] EMF & $\begin{array}{c}\text { [2] http: } \\
\text { //images.philips. } \\
\text { com/is/content/ } \\
\text { PhilipsConsumer } \\
\text { PDFDownloads/ } \\
\text { Global/Services/ } \\
\text { ODLI20170905_- } \\
\text { 001-UPD-en_- } \\
\text { AA-7035_- } \\
\text { Philips- } \\
\text { Managed_- } \\
\text { Services_Digi_ } \\
\text { WTO_01_- } \\
\text { digital-version. } \\
\text { pdf }\end{array}$ \\
\hline $\begin{array}{l}\text { Philips Lighting } \\
\text { (CityTouch) }\end{array}$ & $\begin{array}{l}\text { Street } \\
\text { lighting }\end{array}$ & $\begin{array}{l}\text { Tracking of products and } \\
\text { parts. Monitoring of energy } \\
\text { use and environmental factors. } \\
\text { Remote control and automatic } \\
\text { dimming. Allows managers } \\
\text { to optimize asset use time and } \\
\text { predictively maintain their } \\
\text { system. By increasing the } \\
\text { ability to manage } \\
\text { heterogeneous use cycles of } \\
\text { the different asset components } \\
\text { in detail, the model enables } \\
\text { the looping of assets or asset } \\
\text { components through } \\
\text { additional use cycles. [1] }\end{array}$ & $x$ & $\mathrm{x}$ & $\mathrm{x}$ & $\mathrm{x}$ & & $\begin{array}{l}\text { Extends the use } \\
\text { cycle. Enables } \\
\text { looping of } \\
\text { components } \\
\text { through } \\
\text { additional cycles. } \\
\text { Increased energy } \\
\text { efficiency. [1] }\end{array}$ & $\mathrm{x}$ & & $\mathrm{x}$ & $\mathrm{x}$ & & & [1] EMF & \\
\hline
\end{tabular}


Table A1. Cont.

\begin{tabular}{|c|c|c|c|c|c|c|c|c|c|c|c|c|c|c|c|c|}
\hline \multirow[t]{2}{*}{ Company } & \multirow{2}{*}{$\begin{array}{c}\text { Type of } \\
\text { Product or } \\
\text { Service }\end{array}$} & \multirow[t]{2}{*}{ Description } & \multicolumn{5}{|c|}{ IoT Capability as Categorized } & \multirow[t]{2}{*}{ CE Aspect } & \multicolumn{6}{|c|}{ CE Strategy as Categorized } & \multirow[t]{2}{*}{$\begin{array}{c}\text { Primary } \\
\text { Source }\end{array}$} & \multirow[t]{2}{*}{$\begin{array}{c}\text { Additional } \\
\text { Source(s) }\end{array}$} \\
\hline & & & 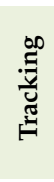 & 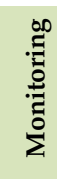 & हैं & 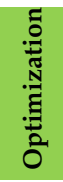 & 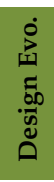 & & 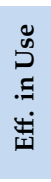 & 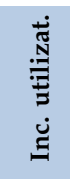 & 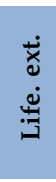 & 苛 & 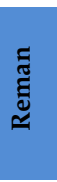 & 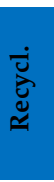 & & \\
\hline $\begin{array}{l}\text { Philips } \\
\text { Lighting } \\
\text { (Hue) }\end{array}$ & Lighting & $\begin{array}{c}\text { Lightbulbs can be } \\
\text { controlled via app [1]. } \\
\text { Automatically turns on } \\
\text { and off based on } \\
\text { monitoring presence and } \\
\text { daylight. [2] }\end{array}$ & & $x$ & $\mathrm{x}$ & & & $\begin{array}{l}\text { Makes your home } \\
\text { "smarter, } \\
\text { comfortable and } \\
\text { energy efficient". }\end{array}$ & $\mathrm{x}$ & & & & & & $\begin{array}{l}\text { [1] Porter } \\
\text { and } \\
\text { Heppelmann }\end{array}$ & $\begin{array}{c}\text { [2] http://www2. } \\
\text { meethue.com/ } \\
\text { en-us/about- } \\
\text { hue/ }\end{array}$ \\
\hline $\begin{array}{l}\text { Rolls-Royce } \\
\text { (TotalCare) }\end{array}$ & Jet engines & $\begin{array}{l}\text { Engine conditions } \\
\text { monitoring gives insight } \\
\text { into how to redesign the } \\
\text { engine [1] and how to } \\
\text { optimize maintenance [2] }\end{array}$ & & $\mathrm{x}$ & & $\mathrm{x}$ & $\mathrm{x}$ & $\begin{array}{l}\text { More productive } \\
\text { and more durable, } \\
\text { long-lasting } \\
\text { design [1]. Better } \\
\text { planned } \\
\text { maintenance and } \\
\text { repair. [2] }\end{array}$ & $\mathrm{x}$ & & $x$ & & & & [1] EMF & $\begin{array}{c}\text { [2] https://www. } \\
\text { rolls-royce.com/ } \\
\text { media/our- } \\
\text { stories/discover/ } \\
\text { 2017/totalcare. } \\
\text { aspx }\end{array}$ \\
\hline
\end{tabular}


Table A1. Cont.

\begin{tabular}{|c|c|c|c|c|c|c|c|c|c|c|c|c|c|c|c|c|}
\hline \multirow[t]{2}{*}{ Company } & \multirow{2}{*}{$\begin{array}{c}\text { Type of } \\
\text { Product or } \\
\text { Service }\end{array}$} & \multirow[t]{2}{*}{ Description } & \multicolumn{5}{|c|}{ IoT Capability as Categorized } & \multirow[t]{2}{*}{ CE Aspect } & \multicolumn{6}{|c|}{ CE Strategy as Categorized } & \multirow[t]{2}{*}{$\begin{array}{l}\text { Primary } \\
\text { Source }\end{array}$} & \multirow[t]{2}{*}{$\begin{array}{l}\text { Additional } \\
\text { Source(s) }\end{array}$} \\
\hline & & & 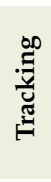 & 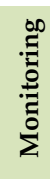 & 㝘 & 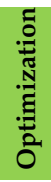 & 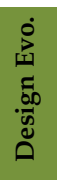 & & 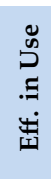 & 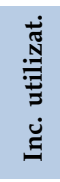 & 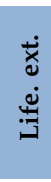 & 气̃ & 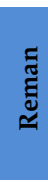 & 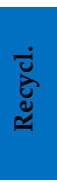 & & \\
\hline $\begin{array}{l}\text { Schneider } \\
\text { Electric }\end{array}$ & $\begin{array}{c}\text { Building } \\
\text { management } \\
\text { systems }\end{array}$ & $\begin{array}{l}\text { Gathers data about } \\
\text { energy use and other } \\
\text { building performance } \\
\text { metrics. Uses monitoring } \\
\text { and, for some customers, } \\
\text { remote control to } \\
\text { minimize energy } \\
\text { consumption [1] }\end{array}$ & & $x$ & $x$ & $\mathrm{x}$ & & $\begin{array}{l}\text { Minimize energy } \\
\text { consumption. [1] }\end{array}$ & $x$ & & & & & & $\begin{array}{c}\text { [1] Porter } \\
\text { and } \\
\text { Heppelmann }\end{array}$ & $\begin{array}{l}\text { [2] https://www } \\
\text { schneider- } \\
\text { electric.com/en/ } \\
\text { work/solutions/ } \\
\text { system/s4/ } \\
\text { building- } \\
\text { systems- } \\
\text { smartstruxure/ }\end{array}$ \\
\hline $\begin{array}{l}\text { Sensity } \\
\text { Systems }\end{array}$ & $\begin{array}{l}\text { Lighting } \\
\text { control } \\
\text { system }\end{array}$ & $\begin{array}{l}\text { Monitors presence of } \\
\text { people and automatically } \\
\text { adjusts lighting based on } \\
\text { that [1] }\end{array}$ & & $\mathrm{x}$ & $\mathrm{x}$ & & & $\begin{array}{l}\text { Lighting owners } \\
\text { are able to reduce } \\
\text { energy costs and } \\
\text { implement a } \\
\text { variety of "Smart } \\
\text { City" applications } \\
\text { and services. [2] }\end{array}$ & $\mathrm{x}$ & & & & & & [1] EMF & $\begin{array}{c}\text { [2] http: } \\
\text { //www.verizon. } \\
\text { com/about/ } \\
\text { news/verizon- } \\
\text { accelerates- } \\
\text { smart- } \\
\text { communities- } \\
\text { acquisition- } \\
\text { sensity-systems }\end{array}$ \\
\hline Spire & $\begin{array}{c}\text { Satellite-based } \\
\text { data } \\
\text { monitoring }\end{array}$ & $\begin{array}{l}\text { Tracking of e.g. trucks, } \\
\text { aircrafts and trains. Spire } \\
\text { also collects other kinds } \\
\text { of data, about for } \\
\text { example weather and } \\
\text { climate. [1] }\end{array}$ & $x$ & & & & & $\begin{array}{l}\text { Enabling lowered } \\
\text { fuel consumption } \\
\text { from optimal } \\
\text { routing. [1] }\end{array}$ & $x$ & & & & & & [1] EMF & $\begin{array}{c}\text { [2] https://spire } \\
\text { com/data/ }\end{array}$ \\
\hline Sunpower & Solar panels & $\begin{array}{c}\text { Monitors energy output } \\
\text { and performance. } \\
\text { Connects to other devices } \\
\text { in the home to optimize } \\
\text { the timing of activities in } \\
\text { a way that matches } \\
\text { power generation from } \\
\text { the solar power system. } \\
\text { [1] }\end{array}$ & & $x$ & $x$ & $\mathrm{x}$ & & $\begin{array}{l}\text { Improved energy } \\
\text { management. [1] }\end{array}$ & $x$ & & & & & & [1] EMF & $\begin{array}{l}\text { [2] https: } \\
\text { //us.sunpower. } \\
\text { com/business- } \\
\text { government/ } \\
\text { large- } \\
\text { commercial/ } \\
\text { sunpower- } \\
\text { commercial/ }\end{array}$ \\
\hline
\end{tabular}


Table A1. Cont.

\begin{tabular}{|c|c|c|c|c|c|c|c|c|c|c|c|c|c|c|c|c|}
\hline \multirow[t]{2}{*}{ Company } & \multirow{2}{*}{$\begin{array}{c}\text { Type of } \\
\text { Product or } \\
\text { Service } \\
\end{array}$} & \multirow[t]{2}{*}{ Description } & \multicolumn{5}{|c|}{ IoT Capability as Categorized } & \multirow[t]{2}{*}{ CE Aspect } & \multicolumn{6}{|c|}{ CE Strategy as Categorized } & \multirow{2}{*}{$\begin{array}{l}\text { Primary } \\
\text { Source }\end{array}$} & \multirow[t]{2}{*}{$\begin{array}{c}\text { Additional } \\
\text { Source(s) }\end{array}$} \\
\hline & & & 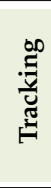 & 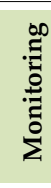 & है & 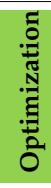 & 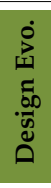 & & 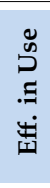 & 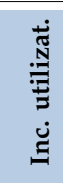 & 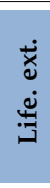 & 苋 & 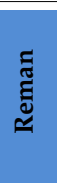 & 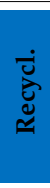 & & \\
\hline Tesla & $\begin{array}{l}\text { Electric } \\
\text { vehicles }\end{array}$ & $\begin{array}{l}\text { Fault monitoring. Car } \\
\text { can schedules repairs } \\
\text { autonomously. Remote } \\
\text { service and upgrades. } \\
\text { Learn from real world } \\
\text { performance in design } \\
\text { improvements. [1] }\end{array}$ & & $x$ & $\mathrm{x}$ & & $\mathrm{x}$ & $\begin{array}{l}\text { Fault detection, } \\
\text { service, repairs, } \\
\text { and upgrades. [1] }\end{array}$ & & & $\mathrm{x}$ & & & & $\begin{array}{l}\text { [1] Porter } \\
\text { and } \\
\text { Heppelmann }\end{array}$ & \\
\hline TOMRA & $\begin{array}{c}\text { Reverse } \\
\text { vending } \\
\text { machines }\end{array}$ & $\begin{array}{l}\text { Measures material } \\
\text { composition and uses } \\
\text { decision-making } \\
\text { algorithm to separate } \\
\text { waste. Can communicate } \\
\text { location and load to } \\
\text { enable route planning. } \\
\text { [1] Notifications if it } \\
\text { needs service. [2] }\end{array}$ & $\mathrm{x}$ & $x$ & & & & $\begin{array}{l}\text { Precise and } \\
\text { efficient recycling. } \\
\text { [1] Maintenance } \\
\text { of machine. [2] }\end{array}$ & $\mathrm{x}$ & & $x$ & & & $x$ & [1] EMF & $\begin{array}{l}\text { [2] https://www. } \\
\text { tomra.com/en/ } \\
\text { collection/ } \\
\text { reverse- } \\
\text { vending/digital }\end{array}$ \\
\hline Trane & HVAC & $\begin{array}{l}\text { Company as moved from } \\
\text { focussing on HVAC } \\
\text { equipment production to } \\
\text { complete building } \\
\text { performance [1]. Mobile } \\
\text { platform to control and } \\
\text { manage buildings more } \\
\text { efficiently, reducing cost } \\
\text { and providing a better } \\
\text { indoor environment } \\
\text { while energy efficiency is } \\
\text { maximized. Monitoring } \\
\text { of e.g. refrigerant leaks } \\
\text { can give remote alarms to } \\
\text { control system. [2] }\end{array}$ & & $x$ & $\mathrm{x}$ & $\mathrm{x}$ & & $\begin{array}{c}\text { Optimize } \\
\text { performance and } \\
\text { energy efficiency } \\
{[2]}\end{array}$ & $\mathrm{x}$ & & & & & & $\begin{array}{l}\text { [1] Porter } \\
\text { and } \\
\text { Heppelmann }\end{array}$ & $\begin{array}{c}\text { [2] } \\
\text { https://www. } \\
\text { trane.com/ } \\
\text { commercial/ } \\
\text { global/europe/ } \\
\text { en/controls/ } \\
\text { building- } \\
\text { management- } \\
\text { controls.html }\end{array}$ \\
\hline
\end{tabular}


Table A1. Cont.

\begin{tabular}{|c|c|c|c|c|c|c|c|c|c|c|c|c|c|c|c|c|}
\hline \multirow[t]{2}{*}{ Company } & \multirow{2}{*}{$\begin{array}{c}\text { Type of } \\
\text { Product or } \\
\text { Service }\end{array}$} & \multirow[t]{2}{*}{ Description } & \multicolumn{5}{|c|}{ IoT Capability as Categorized } & \multirow[t]{2}{*}{ CE Aspect } & \multicolumn{6}{|c|}{ CE Strategy as Categorized } & \multirow{2}{*}{$\begin{array}{c}\text { Primary } \\
\text { Source }\end{array}$} & \multirow[t]{2}{*}{$\begin{array}{c}\text { Additional } \\
\text { Source(s) }\end{array}$} \\
\hline & & & 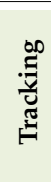 & 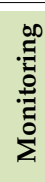 & 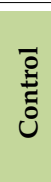 & 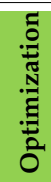 & 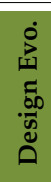 & & $\begin{array}{l}\tilde{D} \\
. \\
\Xi \\
\ddot{ \pm}\end{array}$ & 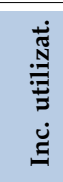 & $\begin{array}{l}\dot{\vec{x}} \\
\stackrel{0}{\grave{H}}\end{array}$ & 苞 & 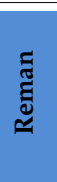 & 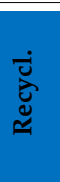 & & \\
\hline Whirlpool & $\begin{array}{l}\text { Washing } \\
\text { machines }\end{array}$ & $\begin{array}{l}\text { Monitors washing cycles. } \\
\text { Remote control through } \\
\text { app [3]. Maintenance } \\
\text { notifications. Connected } \\
\text { to NEST to find optimal } \\
\text { time for washing. [2] }\end{array}$ & & $x$ & $\mathrm{x}$ & $x$ & & $\begin{array}{c}\text { Predictive } \\
\text { maintenance } \\
\text { notification. [3] } \\
\text { Connected to } \\
\text { NEST to plan } \\
\text { washing to save } \\
\text { energy and avoid } \\
\text { grid-peaks. [2] }\end{array}$ & $x$ & & $\mathrm{x}$ & & & & $\begin{array}{c}\text { [1] Porter } \\
\text { and } \\
\text { Heppelmann }\end{array}$ & $\begin{array}{l}\text { [2] https://www. } \\
\text { whirlpool.com/ } \\
\text { home- } \\
\text { innovations/ } \\
\text { connected- } \\
\text { appliances.html } \\
\text { http://www. } \\
\text { whirlpool.co. } \\
\text { uk/world-of- } \\
\text { whirlpool/ } \\
\text { connectivity. } \\
\text { content.html }\end{array}$ \\
\hline Zipcar & $\begin{array}{c}\text { Car-sharing } \\
\text { service }\end{array}$ & $\begin{array}{l}\text { Vehicle tracking help } \\
\text { users find the car when } \\
\text { they need it. Vehicle } \\
\text { telematics allows Zipcar } \\
\text { to monitors driver } \\
\text { behaviour and } \\
\text { understand how vehicles } \\
\text { are being used, ultimately } \\
\text { leading to better service } \\
\text { availability for members } \\
\text { [2]. The cars are unlocked } \\
\text { by the user who has } \\
\text { reserved it, with mobile } \\
\text { application [3]. }\end{array}$ & $\mathrm{x}$ & $x$ & $\mathrm{x}$ & & $\mathrm{x}$ & $\begin{array}{c}\text { Real-time access } \\
\text { to vehicles when } \\
\text { needed. [1] }\end{array}$ & & $\mathrm{x}$ & & & & & $\begin{array}{c}\text { [1] Porter } \\
\text { and } \\
\text { Heppelmann }\end{array}$ & $\begin{array}{l}\text { [2] http://www. } \\
\text { zipcar.be/en/ } \\
\text { static/privacy } \\
\text { http://www. } \\
\text { zipcar.be/en/ } \\
\text { how-it-works }\end{array}$ \\
\hline
\end{tabular}




\section{References}

1. Ellen MacArthur Foundation. Towards the Circular Economy: Economic and Business Rationale for an Accelerated Transition; Ellen MacArthur Foundation: London, UK, 2013.

2. Lieder, M.; Rashid, A. Towards circular economy implementation: A comprehensive review in context of manufacturing industry. J. Clean. Prod. 2016, 115, 36-51. [CrossRef]

3. Balkenende, R.; Bocken, N.; Bakker, C. Design for the Circular Economy. In The Routledge Handbook of Sustainable Design; Egenhoefer, R.B., Ed.; Routledge: London, UK, 2017; pp. 1-19. [CrossRef]

4. Bocken, N.; De Pauw, I.; Bakker, C.; Van Der Grinten, B. Product design and business model strategies for a circular economy. J. Ind. Prod. Eng. 2016, 33, 308-320. [CrossRef]

5. Qu, M.; Yu, S.; Chen, D.; Chu, J.; Tian, B. State-of-the-art of design, evaluation, and operation methodologies in product service systems. Comput. Ind. 2016, 77, 1-14. [CrossRef]

6. Tukker, A. Product services for a resource-efficient and circular economy-a review. J. Clean. Prod. 2015, 97, 76-91. [CrossRef]

7. Manzini, E.; Vezzoli, C. A strategic design approach to develop sustainable product service systems: Examples taken from the 'environmentally friendly innovation' Italian prize. J. Clean. Prod. 2003, 11, 851-857. [CrossRef]

8. Atzori, L.; Iera, A.; Morabito, G. The Internet of Things: A survey. Comput. Netw. 2010, 54, $2787-2805$. [CrossRef]

9. Whitmore, A.; Agarwal, A.; Da Xu, L. The Internet of Things-A survey of topics and trends. Inf. Syst. Front. 2015, 17, 261-274. [CrossRef]

10. Ellen MacArthur Foundation. Intelligent Assets: Unlocking the Circular Economy Potential; Ellen MacArthur Foundation: London, UK, 2016.

11. GESI and Accenture. \#SystemTransformation: How Digital Solutions Will Drive Progress towards the Sustainable Development Goals; Global e-Sustainability Initiative (GeSI): Brussels, Belgium, 2016.

12. Lacy, P. Using digital tech to spin the circular economy. Accenture Outlook. 2015. Available online: https://www.accenture.com/cr-en/insight-outlook-using-digital-tech-spin (accessed on 25 September 2019).

13. Ng, I.C.L.; Wakenshaw, S.Y.L. The Internet-of-Things: Review and research directions. Int. J. Res. Mark. 2017, 34, 3-21. [CrossRef]

14. Stankovic, J.A. Research directions for the internet of things. IEEE Internet Things J. 2014, 1, 3-9. [CrossRef]

15. Li, S.; Da Xu, L.; Zhao, S. The internet of things: A survey. Inf. Syst. Front. 2015, 17, 243-259. [CrossRef]

16. Porter, M.E.; Heppelmann, J.E. How smart, connected products are transforming competition. Harv. Bus. Rev. 2014. Available online: https://hbr.org/2014/11/how-smart-connected-products-aretransforming-competition (accessed on 25 September 2019).

17. Kortuem, G.; Kawsar, F.; Fitton, D.; Sundramoorthy, V. Smart objects as building blocks for the internet of things. IEEE Internet Comput. 2010, 14, 44-51. [CrossRef]

18. Baines, T.; Lightfoot, H. Information and Communication Technologies. In Made to Serve: How Manufacturers Can Compete through Servitization and Product-Service Systems; Baines, T., Lightfoot, H., Eds.; John Wiley \& Sons Incorporated: Chichester, UK, 2013; pp. 169-180. [CrossRef]

19. Alcayaga, A.; Wiener, M.; Hansen, E.G. Towards a Framework of Smart-Circular Systems: An Integrative Literature Review. J. Clean. Prod. 2019, 221, 622-634. [CrossRef]

20. Nobre, G.C.; Tavares, E. Scientific literature analysis on big data and internet of things applications on circular economy: A bibliometric study. Scientometrics 2017, 111, 463-492. [CrossRef]

21. Tseng, M.L.; Tan, R.R.; Chiu, A.S.F.; Chien, C.F.; Kuo, T.C. Circular economy meets industry 4.0: Can big data drive industrial symbiosis? Resour. Conserv. Recycl. 2018, 131, 146-147. [CrossRef]

22. Okorie, O.; Salonitis, K.; Charnley, F.; Moreno, M.; Turner, C.; Tiwari, A. Digitisation and the Circular Economy: A Review of Current Research and Future Trends. Energies 2018, 11, 3009. [CrossRef]

23. Pagoropoulos, A.; Pigosso, D.C.A.; McAloone, T.C. The Emergent Role of Digital Technologies in the Circular Economy: A Review. Procedia CIRP 2017, 64, 19-24. [CrossRef]

24. Salminen, V.; Ruohomaa, H.; Kantola, J. Digitalization and Big Data Supporting Responsible Business Co-Evolution. In Advances in Human Factors, Business Management, Training and Education; Kantola, J.I., Barath, T., Nazir, S., Andre, T., Eds.; Springer International Publishing: Switzerland, 2017; pp. 1055-1067. [CrossRef] 
25. Spring, M.; Araujo, L. Product biographies in servitization and the circular economy. Ind. Mark. Manag. 2017, 60, 126-137. [CrossRef]

26. Jensen, J.P.; Remmen, A. Enabling Circular Economy Through Product Stewardship. Procedia Manuf. 2017, 8, 377-384. [CrossRef]

27. Roy, R.; Stark, R.; Tracht, K.; Takata, S.; Mori, M. Continuous maintenance and the future-Foundations and technological challenges. Cirp Ann. Manuf. Technol. 2016, 65, 667-688. [CrossRef]

28. De Sousa Jabbour, A.B.L.; Jabbour, C.J.C.; Godinho Filho, M.; Roubaud, D. Industry 4.0 and the circular economy: A proposed research agenda and original roadmap for sustainable operations. Ann. Oper. Res. 2018, 270, 273-286. [CrossRef]

29. Gligoric, N.; Krco, S.; Hakola, L.; Vehmas, K.; De, S.; Moessner, K.; Jansson, K.; Polenz, I.; Van Kranenburg, R. SmartTags: IoT Product Passport for Circular Economy Based on Printed Sensors and Unique Item-Level Identifiers. Sensors 2019, 19, 586. [CrossRef] [PubMed]

30. Lightfoot, H.W.; Baines, T.; Smart, P. Examining the information and communication technologies enabling servitized manufacture. Proc. Inst. Mech. Eng. Part B J. Eng. Manuf. 2011, 225, 1964-1968. [CrossRef]

31. Fargnoli, M.; Lleshaj, A.; Lombardi, M.; Sciarretta, N.; Di Gravio, G. A BIM-based PSS approach for the management of maintenance operations of building equipment. Buildings 2019, 9, 139. [CrossRef]

32. Grubic, T.; Jennions, I. Remote monitoring technology and servitised strategies-factors characterising the organisational application. Int. J. Prod. Res. 2018, 56, 2133-2149. [CrossRef]

33. Ardolino, M.; Saccani, N.; Gaiardelli, P.; Rapaccini, M. Exploring the Key Enabling Role of Digital Technologies for PSS Offerings. Procedia CIRP 2016, 47, 561-566. [CrossRef]

34. Ardolino, M.; Rapaccini, M.; Saccani, N.; Gaiardelli, P.; Crespi, G.; Ruggeri, C. The role of digital technologies for the service transformation of industrial companies. Int. J. Prod. Res. 2018, 56, 2116-2132. [CrossRef]

35. Lindström, J.; Hermanson, A.; Hellis, M.; Kyösti, P. Optimizing Recycling Management Using Industrial Internet Supporting Circular Economy: A Case Study of an Emerging IPS 2. Procedia CIRP 2017, 64, 55-60. [CrossRef]

36. Kiritsis, D. Closed-loop PLM for intelligent products in the era of the Internet of things. Comput. Aided Des. 2011, 43, 479-501. [CrossRef]

37. Moreno, M.; Turner, C.; Tiwari, A.; Hutabarat, W.; Charnley, F.; Widjaja, D.; Mondini, L. Re-distributed Manufacturing to Achieve a Circular Economy: A Case Study Utilizing IDEF0 Modeling. Procedia CIRP 2017, 63, 686-691. [CrossRef]

38. Bressanelli, G.; Adrodegari, F.; Perona, M.; Saccani, N. Exploring How Usage-Focused Business Models Enable Circular Economy through Digital Technologies. Sustainability 2018, 10, 639. [CrossRef]

39. Mays, N.; Roberts, E.; Popay, J. Synthesising research evidence. In Studying the Organisation and Delivery of Health Services: Research Methods; Fulop, N., Allen, P., Clarke, A., Black, N., Eds.; Routledge: London, UK, 2001; pp. 188-220.

40. Grubic, T. Servitization and remote monitoring technology: A literature review and research agenda. J. Manuf. Technol. Manag. 2014, 25, 100-124. [CrossRef]

41. Porter, M.E. How smart, connected products are transforming companies. Harv. Bus. Rev. 2015. Available online: https://hbr.org/2015/10/how-smart-connected-products-are-transforming-companies (accessed on 25 September 2019).

42. Gubbi, J.; Buyya, R.; Marusic, S.; Palaniswami, M. Internet of Things (IoT): A vision, architectural elements, and future directions. Futur. Gener. Comput. Syst. 2013, 29, 1645-1660. [CrossRef]

43. Atzori, L.; Iera, A.; Morabito, G. Understanding the Internet of Things: Definition, potentials, and societal role of a fast evolving paradigm. Ad Hoc Netw. 2016, 56, 122-140. [CrossRef]

44. Xia, M.; Li, T.; Zhang, Y.; De Silva, C.W. Closed-loop design evolution of engineering system using condition monitoring through internet of things and cloud computing. Comput. Netw. 2016, 101, 5-18. [CrossRef]

45. Bogers, S.; Frens, J.; Van Kollenburg, J.; Deckers, E.; Hummels, C. Connected Baby Bottle: A Design Case Study Towards A Framework for Data-Enabled Design. In Proceedings of the 2016 ACM Conference on Designing Interactive Systems, Brisbane, QLD, Australia, 4-8 June 2016; pp. 301-311. [CrossRef]

46. Atterer, R.; Wnuk, M.; Schmidt, A. Knowing the user's every move: User activity tracking for website usability evaluation and implicit interaction. In Proceedings of the 15th International Conference on World Wide Web, Edinburgh, Scotland, UK, 23-26 May 2006; pp. 203-212. [CrossRef] 
47. Kirchherr, J.; Reike, D.; Hekkert, M. Conceptualizing the circular economy: An analysis of 114 definitions. Resour. Conserv. Recycl. 2017, 127, 221-232. [CrossRef]

48. Geissdoerfer, M.; Savaget, P.; Bocken, N.; Hultink, E.J. Review: The Circular Economy-A new sustainability paradigm? J. Clean. Prod. 2017, 143, 757-768. [CrossRef]

49. Braungart, M.; McDonough, W.; Bollinger, A. Cradle-to-cradle design: Creating healthy emissions-a strategy for eco-effective product and system design. J. Clean. Prod. 2007, 15, 1337-1348. [CrossRef]

50. Tukker, A. Eight types of product-service system: Eight ways to sustainability? Experiences from suspronet. Bus. Strategy Environ. 2004, 13, 246-260. [CrossRef]

51. Den Hollander, M.; Bakker, C.; Hultink, E.J. Product Design in a Circular Economy: Development of a Typology of Key Concepts and Terms. J. Ind. Ecol. 2017, 21, 517-525. [CrossRef]

52. Bakker, C.; Wang, F.; Huisman, J.; den Hollander, M. Products that go round: Exploring product life extension through design. J. Clean. Prod. 2014, 69, 10-16. [CrossRef]

53. Moreno, M.; de los Rios, C.; Rowe, Z.; Charnley, F. A conceptual framework for circular design. Sustainability 2016, 8, 937. [CrossRef]

(C) 2019 by the authors. Licensee MDPI, Basel, Switzerland. This article is an open access article distributed under the terms and conditions of the Creative Commons Attribution (CC BY) license (http://creativecommons.org/licenses/by/4.0/). 